\title{
Functional Influence of Interlaminar Connections in the Hamster's Superior Colliculus
}

\author{
Richard D. Mooney, Xiaoguang Huang, and Robert W. Rhoades \\ Department of Anatomy, Medical College of Ohio, Toledo, Ohio 43699
}

The aim of this study was to determine the functional importance of intrinsic connections within the hamster's superior colliculus (SC) in the development of the visual responses of neurons in the deep layers of this nucleus. We used localized injections of lidocaine to block action potentials of fibers that passed through the superficial layers and injections of $\mathrm{CoCl}_{2}$ to block synaptic transmission in these layers. We also determined the morphology of a number of the deep layer cells recorded in these experiments by intracellular injection of HRP.

Injection of lidocaine into the superficial Jayers completely abolished the visual-and/or optic chiasm-evoked responses of all $\mathbf{4 0}$ deep layer cells tested. Thus, fibers that either pass through or synapse in the superficial layers are necessary for the visual responses of deep layer neurons. Injections of $\mathrm{CoCl}_{2}$ restricted to the superficial layers significantly reduced the visual responsivity of $86 \%$ of 92 deep layer neurons tested and abolished the visual responses of $68 \%$ of these cells. Superficial layer injections of $\mathrm{CoCl}_{2}$ were equally effective in reducing the responses of neurons with dendrites that ascended into the superficial layers (all seven cells tested and recovered) and those of cells with dendrites restricted to the deep layers (six of seven cells tested and recovered). Injections of $\mathrm{CoCl}_{2}$ into the deep layers, in the region of the cell being recorded, significantly reduced the visual responses of $59 \%$ of 37 cells and abolished the visual responses of $40 \%$ of the neurons tested. Deep $\mathrm{CoCl}_{2}$ injections abolished the visual responses of three of four cells with dendrites restricted to the deep layers and only one of four cells with dendrites that ascended into the superficial layers.

These results indicate that descending interlaminar axons from visually responsive superficial layer cells may be responsible for the visual responsivity of most neurons in the deep SC layers of hamster. Also, some deep layer neurons in this species may receive effective visual input through their dendrites that ascend into the superficial layers, where they are likely to be contacted by retinal axons or axon collaterals of superficial layer cells.

\footnotetext{
Received Sept. 30, 1991; revised Jan. 15, 1992; accepted Jan. 22, 1992.

This work was supported in part by NIH Grants EY 08015 and EY 04170 . We thank Beth Figley, Marcia Eck, Steve Savage, Tod King, and Ann Marie Eckles for excellent technical assistance.

Correspondence should be addressed to Dr. Richard D. Mooney, Department of Anatomy, Medical Collcge of Ohio, CS 10008, Toledo, OH 43699.

Copyright (c) 1992 Society for Neuroscience $0270-6474 / 92 / 122417-16 \$ 05.00 / 0$
}

Many neurons in the deep layers [those ventral to the stratum opticum (SO)] of the superior colliculus (SC) are excited by visual stimuli and/or have their responses to nonvisual (somatosensory and auditory) stimulation modulated by concurrent visual input (e.g., Stein and Arigbede, 1972; Gordon, 1973; Drager and Hubel, 1975; Tiao and Blakemore, 1976; Chalupa and Rhoades, 1977; Meredith and Stein, 1986). Anatomical and physiological studies have suggested that several different pathways may provide visual information to deep layer SC cells and that there may be considerable species variability with respect to the functional importance of these different afferents.

Beckstead and Frankfurter (1983) showed that the stratum griseum intermediale (SGI; the most dorsal of the deep SC layers) in cat, rat, and monkey receives a sparse retinal input. Physiological experiments in cat (Berson and McIlwain, 1982) and intra-axonal recording and injection studies in hamster (Mooney and Rhoades, 1990) demonstrated further that this projection arises from Y-cells. Berson and McIlwain (1982) showed that this "Y-direct" pathway made functional contacts onto deep layer neurons in the cat's SC, but there is no information as to whether this projection is either necessary or sufficient for the visual responses of any deep layer neurons.

Fibers from striate and extrastriate cortical areas innervate all SC layers (e.g., Garey et al., 1968; Kawamura et al., 1974; Updyke, 1977; Baleydier et al., 1983; Segal and Beckstead, 1984; Harvey and Worthington, 1990), but cortical input to SC appears to be necessary for the visual responsivity of all deep layer neurons only in the macaque. Schiller et al. (1974) reported that cooling or ablation of area 17 in this species completely abolished the visual responses of deep layer cells without profoundly altering those of superficial layer neurons. Stein and his coworkers (Stein and Arigbede, 1972; Stein, 1978; Ogasawara et al., 1984) have provided evidence that the "specialized" visual response properties, but not the visual responsivity, of many deep layer cells in the cat SC are dependent upon an input from the posterior suprasylvian cortex.

Corticotectal projections do not appear to contribute significantly to the visual responsivity of deep layer SC cells in either the hamster or rabbit. Both Chalupa and Rhoades (1977) and Finlay et al. (1978) showed that the visual receptive fields of deep layer cells in hamster are not significantly affected by large posterior neocortical lesions that included both striate and extrastriate areas. Stewart et al. (1973) and Graham et al. (1982) have reported the same result for the rabbit.

The visual responsivity of deep layer neurons in hamster and rabbit as well as that of some cells in cat may be supported by 
intra-SC circuits. The dendrites of many deep layer cells ascend into the superficial layers (Viktorov, 1968; Tokunaga and Otani, 1976; Norita, 1980; Mooney et al., 1984; Moschovakis and Karabelas, 1985), and visually responsive neurons in the superficial layers send axons to the deep layers (Sprague, 1975; Grantyn et al., 1984; Mooney et al., 1985, 1988; Moschovakis et al., 1988; Rhoades et al., 1989).

The aim of the present study was to determine whether circuits intrinsic to $\mathrm{SC}$ were involved in the visual responses of deep layer neurons in the hamster. To address this question, we adapted techniques developed by Malpeli (1983) to inactivate small portions of the superficial or deep SC layers reversibly while recording from visually responsive deep layer cells. Lidocaine was used to block action potential conduction through the supcrficial laycrs, and $\mathrm{CoCl}_{2}$ was employed to block synaptic transmission.

\section{Materials and Methods}

Preparation of hamsters for recording. Hamsters $(N=106)$ were anesthetized with sodium pentobarbital $(60 \mathrm{mg} / \mathrm{kg}$, i.p., along with $0.15 \mathrm{ml}$ of a $1.5 \%$ solution of atropine sulfate), the trachea was cannulated, and heart rate leads were affixed to the chest. The animal was then placed in a stereotaxic headholder and the cisterna magna was punctured, the dorsal portion of the first cervical vertebra removed, the dura reflected, and the exposed medulla and spinal cord covered with warm mineral oil. The skull overlying both cerebral cortices was then removed and the dura on both sides was incised and reflected. The corneas were protected with intermittent applications of artificial tears. All wound edges were infiltrated with a long-lasting local anesthetic (Nupercaine, CIBA) and anesthesia with urethane (initial i.p. dose, $0.3 \mathrm{gm} / \mathrm{kg}$ ) was initiated. Paralysis was then induced with gallamine triethiodide (initial i.p. dose, $40 \mathrm{mg} / \mathrm{kg}$ ) and artificial respiration was initiated. Anesthesia and paralysis were maintained with hourly intraperitoneal injections of urethane $(0.3 \mathrm{gm} / \mathrm{kg})$ and gallamine triethiodide $(30 \mathrm{mg} / \mathrm{kg})$, respectively. Heart rate was monitored continuously and rectal temperature was maintained at $37^{\circ} \mathrm{C}$ with a thermostatically controlled heating pad.

We verified the efficacy of our anesthetic regimen by allowing the hamster to recover from paralysis at least once during the recording session. If the animal responded to any mechanical stimulation, including pinch with a pair of serrated forceps (such occurrences were rare), anesthesia was immediately supplemented.

Recording from $S C$ neurons. Superior colliculus cells were recorded using micropipettes $(0.4-0.8 \mu \mathrm{m}$ tips) pulled from Radnotti Microstar capillaries. These were filled with $6 \% \mathrm{HRP}$ dissolved in $0.05 \mathrm{M}$ Tris and $0.3 \mathrm{M} \mathrm{KCl}$ and beveled to resistances of $80-100 \mathrm{M} \Omega$. The electrode was coupled to a Eutectics $400 \mathrm{~A}$ electrometer, the output of which was played over an audiomonitor and displayed on a storage oscilloscope. Action potentials were also converted to standard pulses for the construction of peristimulus time histograms (PSTHs), raster displays, and rate meter records by a Cambridge Instruments CED 1401 interfaced to an IBM PC-AT.

Electrical stimulation. Concentric, bipolar stimulating electrodes were positioned in the optic chiasm (OX) and spinal trigeminal subnucleus interpolaris (SpI). These electrodes were used to deliver 5-500 $\mu \mathrm{A}$ stimulus pulses ( $50 \mu \mathrm{sec}$ duration, isolated from ground). These stimulation sites were used since nearly all visually responsive neurons in both the superficial and deep SC layers respond to OX stimulation and most somatosensory cells in the rostral two-thirds of the SC are excited by electrical stimulation of SpI.

Visual stimulation. Background illumination was maintained at 10 $\mathrm{cd} / \mathrm{m}^{2}$, and spots and bars $1.0-2.0 \log$ units above background were used for stimulation. These were presented on a screen upon which the location of the optic disk was back projected using the method of Fernald and Chase (1971). Corrective lenses were not employed since a small eye such as that of a hamster has an extremely large depth of focus (Chalupa and Rhoades, 1978; Powers and Green, 1978). Receptive field characteristics (see below) were initially assessed qualitatively with handheld stimuli. They were then tested quantitatively using a Picasso visual stimulator (Innisfree Inc.).

Somatosensory stimulation. Somatosensory responses were tested in the manner described by Rhoades et al. (1983). Innocuous cutaneous stimuli consist of air puffs; light taps with a camel hair brush, blunt probe, or von Frey hairs; and joint rotation. Noxious stimulation was accomplished by pinching with serrated forceps. The pinch used was of sufficient intensity to be judged as painful when delivered to the back of the experimenter's hand. Automated stimulation of somatosensory cells in the deep SC layers was restricted to those neurons that possessed low-threshold or wide-dynamic-range receptive fields. The responses of these neurons [nearly $85 \%$ of the unimodal somatosensory neurons and all of the bimodal (visual-somatosensory) cells in the deep layers of the hamster's SC (Rhoades et al., 1983; Larson et al., 1987)] were quantified with an air-puff stimulator of the type described by Janig et al. (1977) and used previously by Rhoades et al. (1986) and Mooney et al. (1990).

Analysis of somatosensory responses was used mainly to gain information about both the unintended spread of superficial layer $\mathrm{CoCl}_{2}$ and lidocaine injections into the deep layers and also the effectiveness of deep layer $\mathrm{CoCl}_{2}$ injections (see below).

$\mathrm{CoCl}$, and lidocaine injection. $\mathrm{CoCl}_{2}(10 \mathrm{~mm}$ ) or lidocaine $\mathrm{HCl}$ (a $4 \%$ solution) was injected using Medical Systems BH-2 micropressure units. We calibrated this system by making multiple injections into calibrated Microtrol ${ }^{\circledast}$ capillary tubes; 10 psi $\times 1 \mathrm{sec}$ resulted in an ejection of 15 $\pm 5 \mathrm{nl}$. Electrodes used for superficial layer injections were doublebarrel pipettes. One barrel was filled with either lidocaine or $\mathrm{CoCl}_{2}$, and the second barrel contained either a sharpened tungsten wire or carbon filament for recording single- and multiple-unit activity at the injection site. For experiments where $\mathrm{CoCl}_{2}$ was injected into the deep layers, the second barrel was an HRP-filled pipette of the type described above.

Experimental paradigm. The basic experimental paradigm for all of the experiments took the following form. After the $\mathrm{CoCl}_{2}$-filled, lidocaine-filled, or monitoring electrode was positioned in the superficial layers, an HRP-filled recording electrode or a double-barrel pipette with $\mathrm{CoCl}_{2}$ in one barrel and HRP in the other was advanced into the deep layers until a visually responsive cell with a receptive field overlapping that of the activity recorded by the superficial layer electrode was recorded. The visually and OX-evoked responses of the deep layer cell were then noted, and the visual stimulus that yielded the best response (maximum total spikes per stimulus presentation) was determined. A PSTH was collected using this stimulus, a second PSTH was collected during ejection of $\mathrm{CoCl}_{2}$ or lidocaine, and a recovery PSTH was also collected. The effects of lidocaine or $\mathrm{CoCl}_{2}$ ejection upon the incidence and latency of responses to $\mathrm{OX}$ stimulation were also determined. If the cell was also responsive to either $\mathrm{SpI}$ and/or somatosensory stimuli, the effects of lidocaine or $\mathrm{CoCl}_{2}$ injection upon these responses were also tested.

Preliminary experiments indicated that the volume of tissue silenced by injection of $25 \mathrm{nl}$ of $\mathrm{CoCl}_{2}$ had a diameter under $250 \mu \mathrm{m}$. This was determined in two experiments of the type depicted in Figure 1. Here, $\mathrm{CoCl}_{2}$ (approximately $25 \mathrm{nl}$ per injection; see above) was injected at one point in the stratum griseum superficiale (SGS) and cells were recorded at several locations in the SGS and SO to determine the spread of inactivation. At sites within $150 \mu \mathrm{m}$ of the $\mathrm{CoCl}_{2}$-containing pipette (Fig. $1 A, B$; these rate meter recordings were made at the sites indicated by the corresponding letters in the $\mathrm{SC}$ cross section), single injections of $\mathrm{CoCl}_{2}$ produced near-complete inactivation of visual responses. At sites approximately $250 \mu \mathrm{m}$ away from the $\mathrm{CoCl}_{2}$-containing electrode, even multiple injections (e.g., Fig. $1 D$ ) did not abolish visual responsivity.

Impalement and HRP injection. Neurons were impaled by slowly advancing the micropipette and intermittently passing brief $(250 \mathrm{msec})$ depolarizing current pulses $(0.5-2 \mathrm{nA})$. After penetration, the electrically evoked and sensory responses of the cell were quickly reassessed to determine whether they matched those obtained extracellularly. If they did, the cell was then filled with HRP by passing $5 \mathrm{nA}$ positive current pulses of 250 msec duration at a rate of $1.6 \mathrm{~Hz}$ for as long as intracellular recording was maintained. If possible, response characteristics were tested again at the termination of the HRP injection.

Tissue processing. Upon completion of the recording session, the hamster was given a lethal dose of sodium pentobarbital and perfused through the heart with physiological saline $\left(21^{\circ} \mathrm{C}\right)$ that also contained $20,000 \mathrm{U} /$ liter of heparin and $40 \mathrm{mg} /$ liter of lidocaine. This was followed by at least $500 \mathrm{ml}$ of a fixative that contained $1 \%$ paraformaldehyde, $2.5 \%$ glutaraldehyde, and $4 \%$ sucrose in $0.1 \mathrm{~m}$ sodium phosphate buffer (pH 7.4, $4^{\circ} \mathrm{C}$ ). Brains were postfixed for $12-60 \mathrm{hr}$, cut into $100 \mu \mathrm{m}$ coronal sections, and then processed for the demonstration of HRP reaction product using the method of Adams (1981). Sections were then plated on gelatin-coated slides, dehydrated in absolute ethanol, cleared 

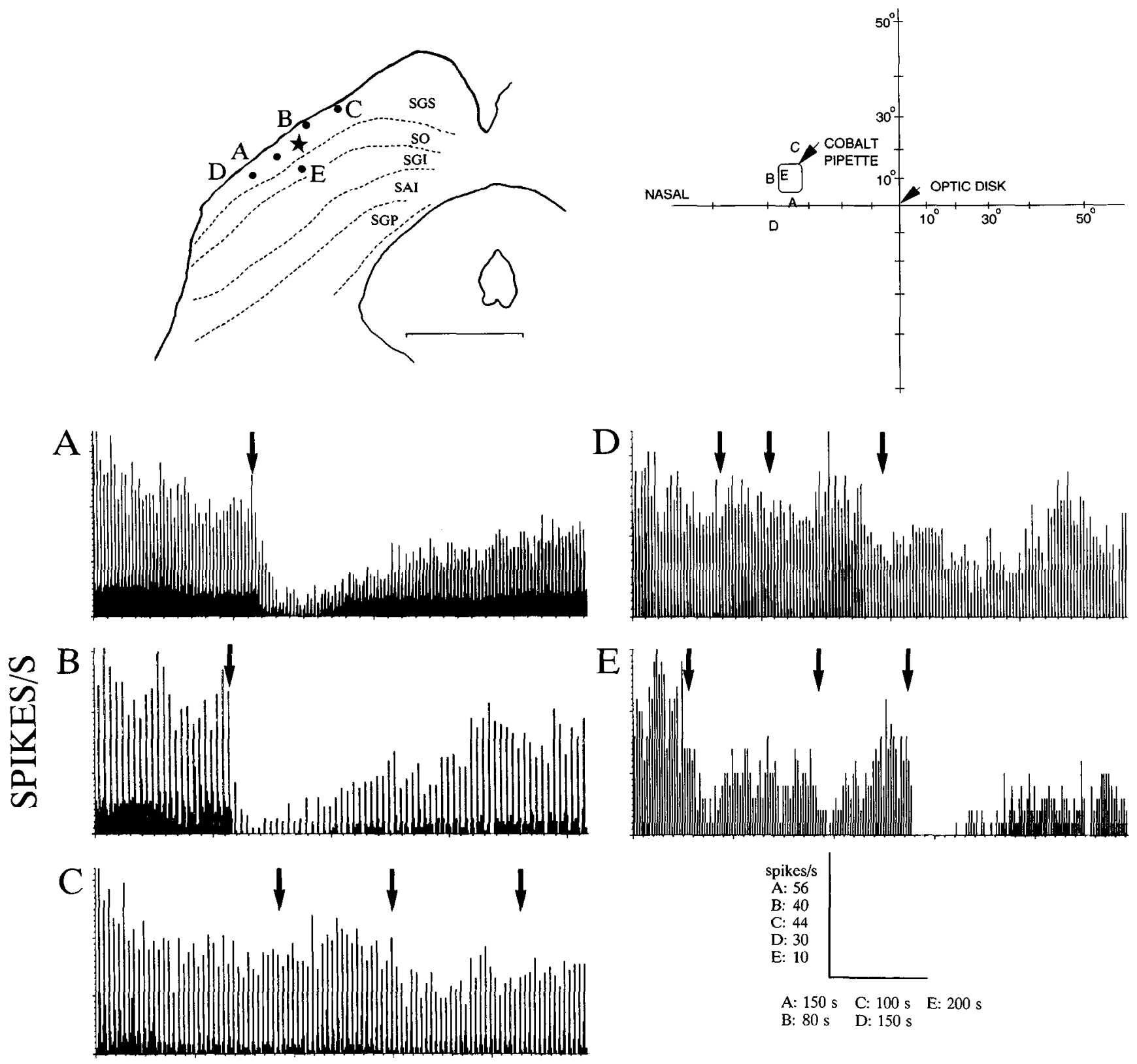

\section{TIME (s)}

Figure 1. Results from a control experiment designed to determine the spread of inactivation produced by injection of CoCl${ }_{2}$. Cobalt chloride was injected at the site denoted by the $s t a r$ in the reconstruction. The rate meter recordings in $A-E$ were made with electrodes located at the sites indicated on the reconstruction. The centers of the receptive fields for the activity recorded at each electrode site are shown in the visual field plot on the upper right. For all of the records, a $5^{\circ}$ spot was flashed for $1 \mathrm{sec}$ every $5 \mathrm{sec}$ in the center of the receptive field. The times of CoCl $\mathrm{C}_{2}$ injections are indicated by the arrows above each rate meter recording. The injection volumes were $25 \mathrm{nl}$ for $A ; 25 \mathrm{nl}$ for $B ; 25,30$, and $35 \mathrm{nl}$ in succession for $C$ and $D$; and 5,10 , and $25 \mathrm{nl}$ in succession for $E$. SAI, stratum album intermedium; $S G P$, stratum griseum profundum. Scale bar (for reconstruction), $500 \mu \mathrm{m}$.

with xylene, and coverslipped. Laminar boundaries were determined by simply examining sections with dark-field optics.

Data analysis. The percentage by which the response of a given cell was reduced was determined by the formula

$$
100 \times\left(1-\frac{\begin{array}{c}
\text { number of spikes in the } \\
\text { experimental PSTH }
\end{array}}{\text { number of spikes in the control PSTH }}\right) \text {. }
$$

Responses were considered to have been significantly suppressed if they were reduced by $50 \%$ after either lidocaine or $\mathrm{CoCl}_{2}$ injections. The visual or OX-evoked responses of a given cell were considered to have been abolished if lidocaine or $\mathrm{CoCl}_{2}$ injection reduced them by more than $90 \%$.

All recovered cells were reconstructed with the Eutectics Neuron Reconstruction System. These reconstructions were used to determine whether a given cell had dendrites that extended into the superficial layers. 
Figure 2. Effects of lidocaine injection into the superficial layers upon superficial layer visual activity and the responses of a deep layer bimodal cell recorded simultaneously. $A$ shows the visual and somatosensory receptive fields of the deep layer cell and that for the multiple-unit visual activity recorded at the site of the lidocaine injection. $B$ contains a raster display and PSTHs that demonstrate the effect of lidocaine injection (2 injections of $30 \mathrm{nl}$, as indicated by the arrows on the raster display) upon the response of the superficial layer activity to OX stimulation. The PSTHs correspond respectively to the periods bracketed in the raster display, and the arrows indicate the time of the OX stimulation. $C$ illustrates the effects of the lidocaine injections upon the OX- and SpI-evoked responses of the deep layer cell. Diagrammatic conventions are the same as above. The upper raster, oscilloscope traces, and PSTHs depict the abolition of the OX evoked response by the lidocaine injections. The lower raster and PSTHS show the lack of effect of another lidocaine injection (a single $30 \mathrm{nl}$ injection at the time indicated by the arrow in the raster display) upon the response evoked by SpI stimulation.

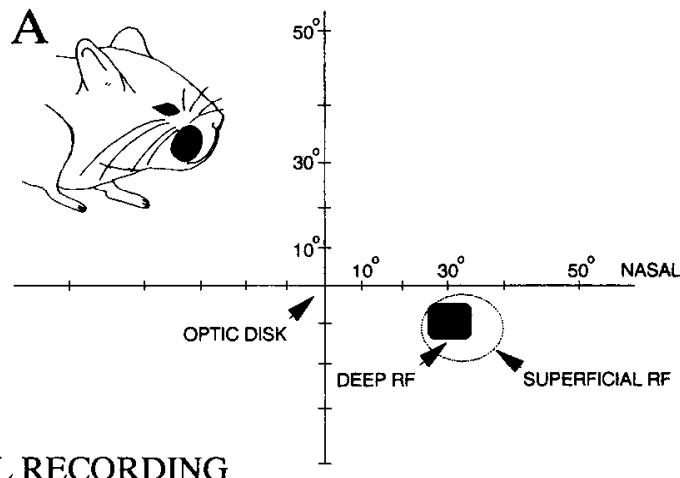

B SUPERFICIAL RECORDING

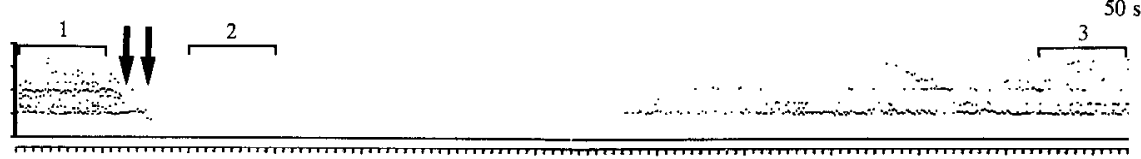

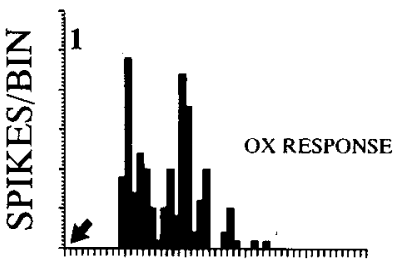

C DEEP CELL
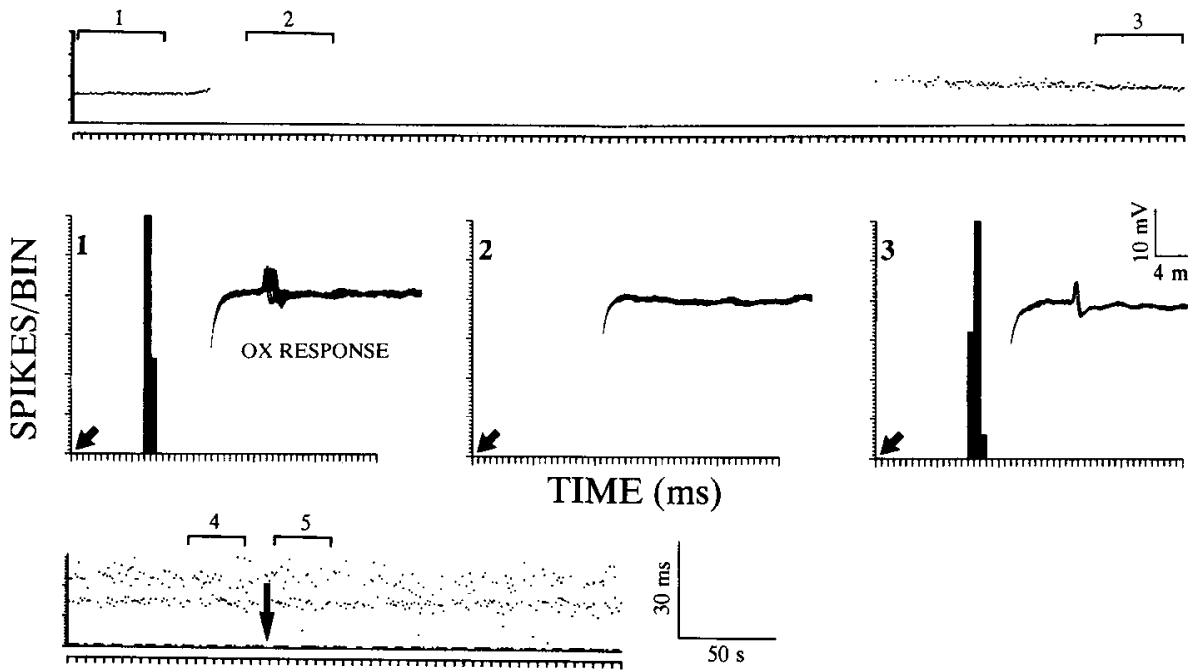

TIME (ms)
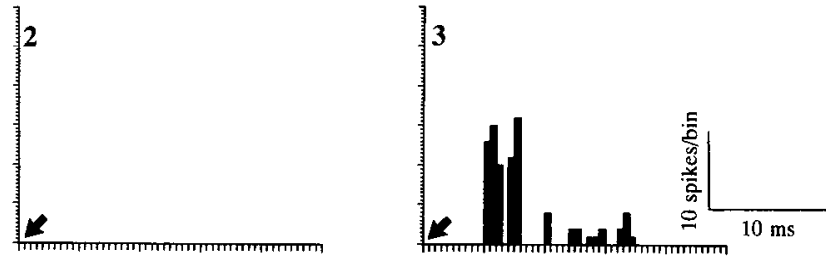
10

TIME (ms)
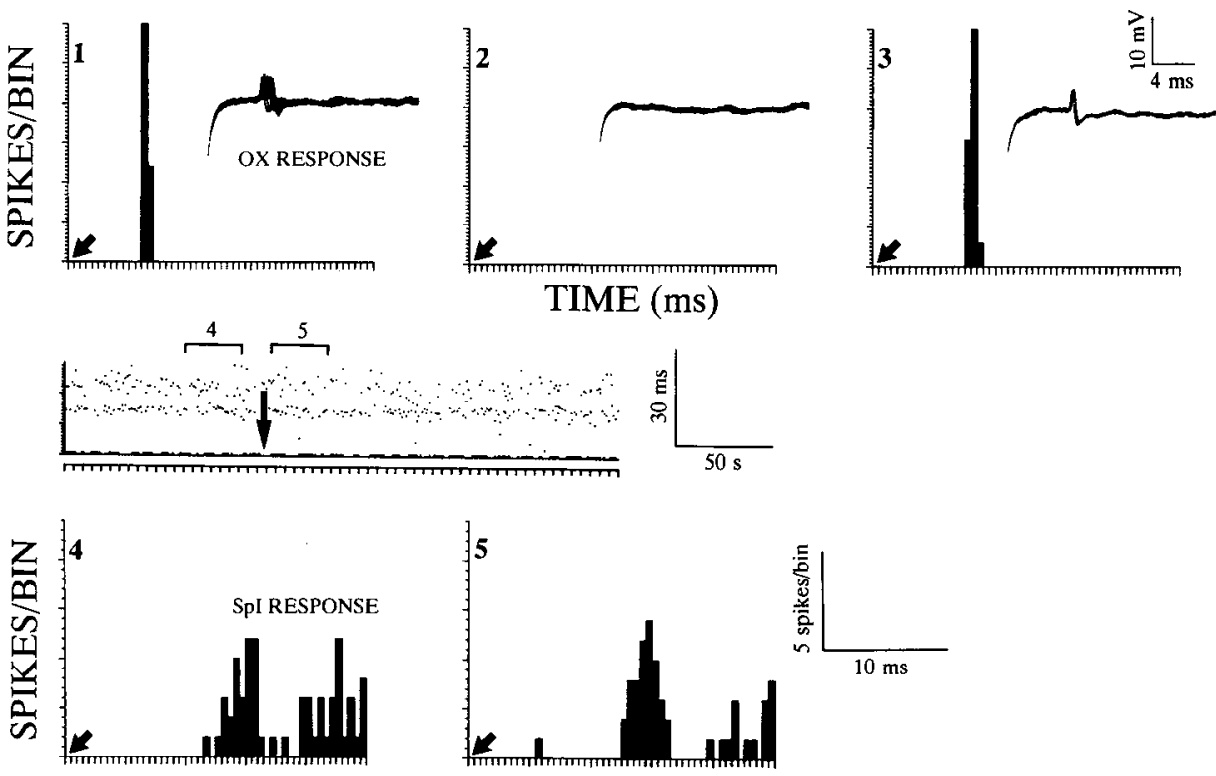

TIME (ms)

\section{Results}

Effects of superficial layer lidocaine injections upon the responses of deep layer visual neurons. While previous studies (Chalupa and Rhoades, 1977; Finlay et al., 1978) have shown that large lesions of the posterior neocortex do not significantly alter the visual responses of deep layer neurons in the hamster's SC, it may be that other pathways to the deep layers not involving the superficial layers could support the visual responses of deep layer neurons. To test this hypothesis, lidocaine was injected into physiologically identified locations in the superficial layers while deep layer cells with overlapping receptive fields were recorded. Such injections should both silence superficial layer SC cells and block action potentials of retinotectal and any other 
A

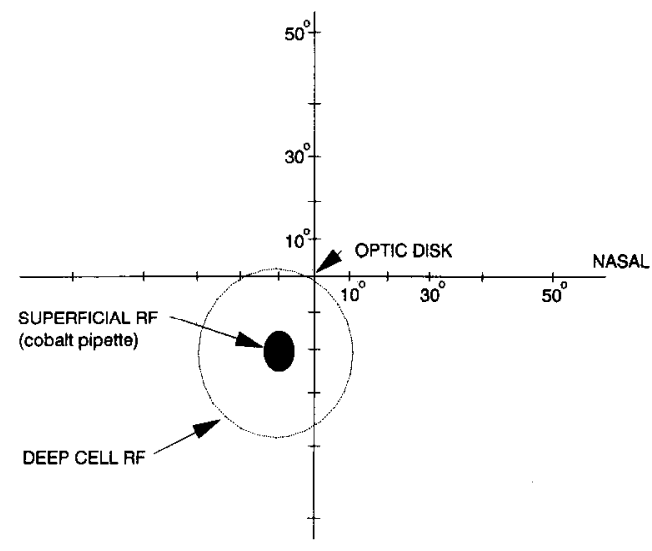

\section{DEEP CELL}
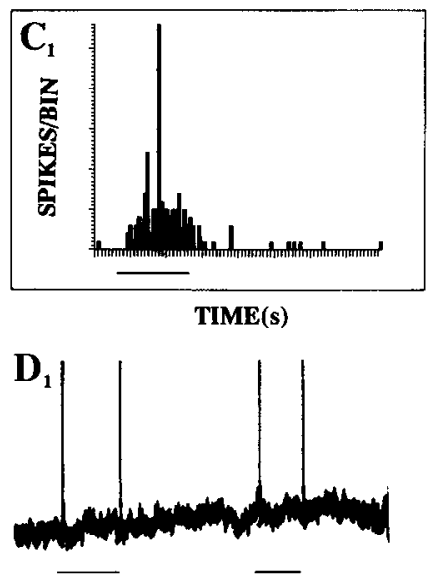

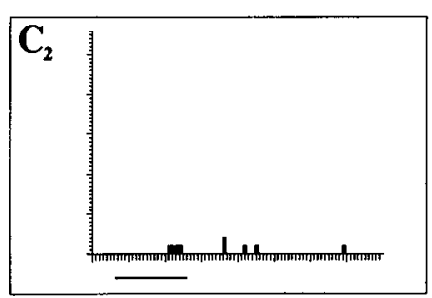

$\mathbf{D}_{2}$

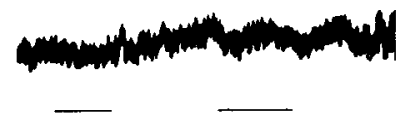

B

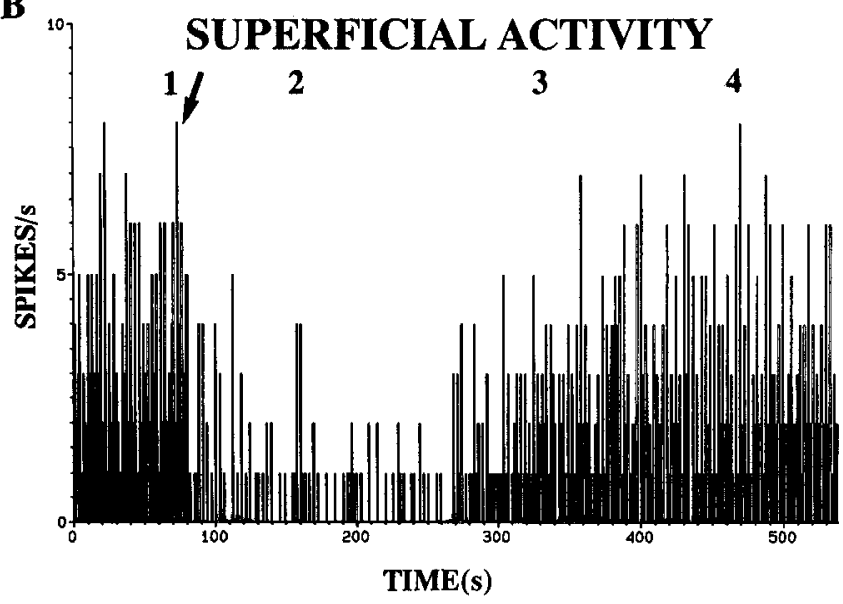

Figure 3. Abolition of the visual responses of a unimodal deep layer neuron by injection of $\mathrm{CoCl}_{2}$ into the superficial layers. $A$ shows the locations of the receptive fields for the deep layer cell and for the multiple-unit activity recorded at the location of the $\mathrm{CoCl}_{2}$-filled pipette in the superficial layers. $B$ shows the effect of a $\mathrm{CoCl}_{2}$ ejection $(30 \mathrm{nl}$ delivered as indicated by the arrow) upon the responses of the superficial layer neurons to a moving spot $\left(5^{\circ} \times 20^{\circ} / \mathrm{sec}\right)$. The PSTHS in $C$ show the response of the deep layer cell to the same spot (10 presentations with the sweep passing across the entire receptive field) before $\left(C_{1}\right)$ and after $\left(C_{2}-C_{t}\right) \mathrm{CoCl}_{2}$ injection. The times at which each of these histograms were made are indicated by the numbers above the rate meter record in $B$; lines below PSTHS indicate the time during which the spot was within the receptive field. $D_{1}-$ $D_{4}$ are oscilloscope traces from a second series after penetration of the cell and show the on-off response to a light flash of the deep layer cell prior to $\mathrm{CoCl}_{2}$ injection $\left(D_{1}\right)$, the loss of the response just after $\mathrm{CoCl}_{2}$ injection $\left(D_{2}\right)$, the fact that the neuron could be fired by current injection $\left(D_{3}\right.$, underline bracket denotes depolarizing ramp) even when the response to visual stimulation had been abolished, and finally, the recovery of the visual response $\left(D_{4}\right)$. The bars beneath the traces in $D_{1}, D_{2}$, and $D_{4}$ indicate the duration of the visual stimulus.

axons that might pass through the superficial layers and synapse in either the superficial or deep layers. If such injections did not abolish visual responsivity, it would indicate strongly that an extrinsic input to the deep layers that did not pass through or synapse in the superficial layers was capable of sustaining the visual responses of deep layer neurons.

We tested 40 deep layer SC neurons with lidocaine injections into the superficial layers. Twenty-one of these cells were also tested with $\mathrm{CoCl}_{2}$, and they are considered again below. The visual-and/or OX-evoked responses of all of these neurons were abolished by lidocaine injections. The average percentage suppression (mean $\pm \mathrm{SD}$ ) was $97.4 \pm 5.9 \%$. The responses of one cell tested in this manner are illustrated in Figure 2. This neuron was bimodal; it had a large receptive field in the lower nasal visual field and also responded to deffection of several rostral and ventral mystacial vibrissae. The cell was also activated by stimulation of either OX or SpI (Fig. 2C). Lidocaine injection into the superficial layers produced a complete blockade of the response normally elicited by $\mathrm{OX}$ stimulation, but had no sig- nificant effect upon the discharges evoked by stimulation of SpI. Four of the cells tested with superficial lidocaine injections responded to somatosensory and/or SpI stimulation. None of these responses were significantly affected by blockade of superficial layer activity.

The fact that all of the deep layer visual cells tested had their visually and/or OX-evoked responses abolished by injection of lidocaine into the superficial layers indicates that fibers either synapsing in, or passing through, these layers were necessary for the visual responsivity of all of these neurons.

Effects of superficial layer $\mathrm{CoCl}_{2}$ injections upon the visual responses of deep layer cells. If the visual responses of a deep layer SC cell were abolished by injection of $\mathrm{CoCl}_{2}$ into the superficial layers, it would mean that synapses in these layers were necessary for those responses. Such a result would indicate that direct retinal projections to deep layer dendrites of the cell being recorded either did not exist or were insufficient to confer visual responsivity upon it. If a cell whose visual responses were abolished by injection of $\mathrm{CoCl}_{2}$ into the superficial layers did not 


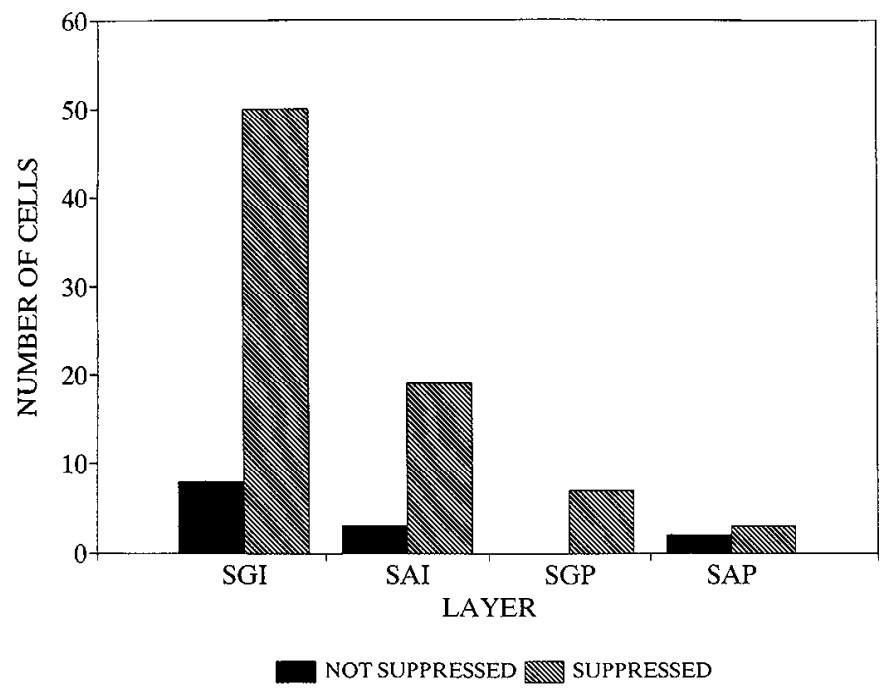

Figure 4. Laminar distributions of deep layer cells that were signif cantly suppressed (hatched bars) or unaffected or had their responses enhanced (solid bars) by injection of $\mathrm{CoCl}_{2}$ into the superficial layers. $S G I$, stratum griseum intermediale; $S A I$, stratum album intermedium; $S G P$, stratum griseum profundum; $S A P$, stratum album profundum.

have dendrites extending into these layers, it would necessitate that a descending projection from the superficial to the deep layers was necessary for the visual responses of the cell in question.

We tested the effects of superficial layer $\mathrm{CoCl}_{2}$ injection upon the visual responses of 92 deep layer visual cells. Of these, $86 \%$ $(N=79)$ had their responses significantly reduced by $\mathrm{CoCl}_{2}$ injections and $68 \%(N=63)$ of the total sample had their visual responses completely abolished. Twelve percent $(N=11)$ were not affected, and the responses of two cells were enhanced by injection of $\mathrm{CoCl}_{2}$ into the superficial layers. The average percentage suppression for all 92 cells was $81 \pm 32 \%$.

While most of the visually responsive neurons tested in the deep layers had large receptive fields with poorly defined borders and visual responses that habituated rapidly with repeated stimulation, 33 of the neurons evaluated had well-defined, movement-sensitive receptive fields; $85 \%(N=28)$ of these neurons had their visual responses significantly suppressed by injection of $\mathrm{CoCl}_{2}$ into the superficial layers, $64 \%(N=21)$ of the total sample had their visual responses completely abolished, and $15 \%(N=5)$ were unaffected. The average percentage suppression for this sample was $77 \pm 35 \%$.

The responses of one deep layer visual neuron whose responses were almost completely abolished by injections of $\mathrm{CoCl}_{2}$ into the superficial layers are shown in Figure 3. This unimodal visual neuron was recorded in the SGI and had a large receptive field in the lower temporal visual field that was centered on that of the multiple-unit activity recorded with the injection electrode in the superficial layers (Fig. 3A). The neuron responded to a moving spot and gave a strong on-response and a more variable off-response to a flashed spot (Fig. $3 C_{1}, D_{1}$ ), all of which were almost completely abolished by $\mathrm{CoCl}_{2}$ injection (Fig. $3 C_{2}, C_{3}, D_{2}$ ) that also suppressed the responsivity of multipleunit activity recorded at the site of the injection pipette (Fig. $3 B$ ). Data collected 7 min after injection of $\mathrm{CoCl}_{2}$ (Fig. $3 C_{4}, D_{4}$ ) indicated a near-complete recovery of the neuron's responses.

There were no significant differences between either the lam-

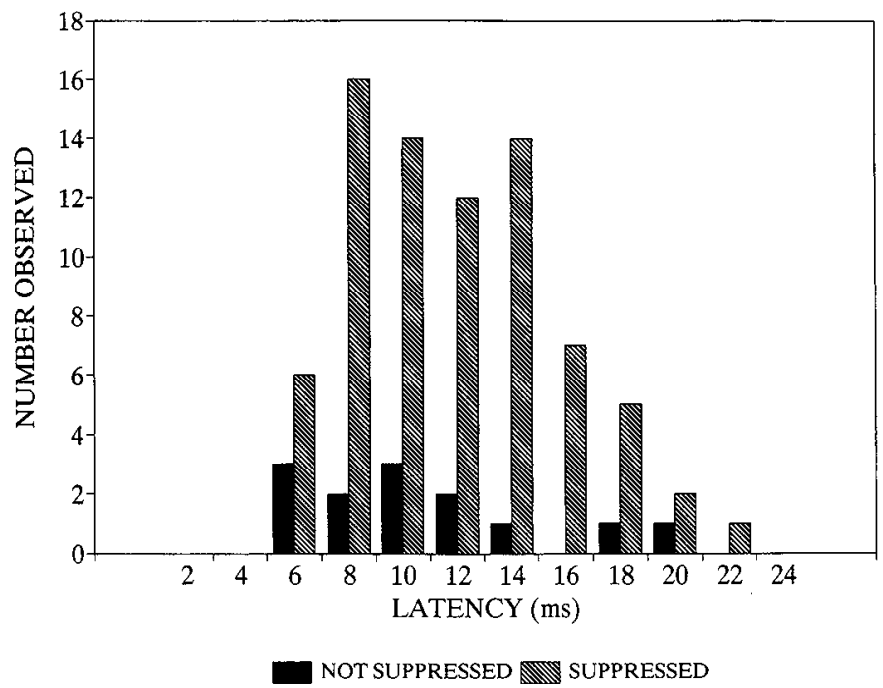

Figure 5. Ilistogram of response latencies to OX stimulation for deep layer cells either that were significantly suppressed by injection of $\mathrm{CoCl}_{2}$ into the superficial layers (hatched bars) or that had their responses enhanced or were unaffected by such injections (solid bars). The mean $( \pm \mathrm{SD})$ latency for the former group was $10.8 \pm 3.8 \mathrm{msec}$, and that for the latter group was $9.8 \pm 4.2 \mathrm{msec}(t=0.9 ; \mathrm{df}=88 ; p=0.36)$.

inar distributions or response properties of the deep layer visual neurons that were or were not significantly suppressed by injection of $\mathrm{CoCl}_{2}$ into the superficial layers. The laminar distributions of the neurons affected in different ways by $\mathrm{CoCl}_{2}$ injection are shown in Figure 4. Most (58) of the cells tested were located in the SGI, and $86 \%$ of these ncurons were suppressed by injection of $\mathrm{CoCl}_{2}$ into the superficial layers. Eighty-six percent of the 22 cells tested in the stratum album intermedium (SAI) were suppressed by superficial layer $\mathrm{CoCl}_{2}$ injections, as were $100 \%$ of the seven cells tested in the stratum griseum profundum (SGP) and $60 \%$ of the five neurons tested in the stratum album profundum (SAP; $\chi^{2}=5.5 ; \mathrm{df}=3 ; p=0.14$ ).

There were also no differences in the average response latencies to OX stimulation for cells that were either significantly suppressed or unaffected by injection of $\mathrm{CoCl}_{2}$ into the superficial SC layers (Fig. 5) $(t=0.9 ; \mathrm{df}=88 ; p=0.36)$. The average response latency to $\mathrm{OX}$ stimulation for the cells that were suppressed by superficial layer $\mathrm{CoCl}_{2}$ injections was $10.8 \pm 3.8$ msec (mean $\pm \mathrm{SD}$ ), and that for cells unaffected by such injections was $9.8 \pm 4.2 \mathrm{msec}$.

Fourteen deep layer cells tested during $\mathrm{CoCl}_{2}$ injection into the superficial layers were successfully impalcd and fillcd with HRP. Several of these neurons are depicted in Figure 6 and reconstructed in Figure 7. Seven of the recovered neurons had dendrites that were restricted to the deep layers, and the visual responses of six of them were suppressed by $\mathrm{CoCl}_{2}$ injection. The remaining cell was not suppressed. Seven cells had dendrites that extended into the superficial layers, and all of these neurons were suppressed by $\mathrm{CoCl}_{2}$ injections.

Effects of deep layer $\mathrm{CoCl}_{2}$ injections upon the visual responses of deep layer cells. If a deep layer neuron's visual responses were not abolished by injection of $\mathrm{CoCl}_{2}$ into the deep SC layers, it would indicate that synapses onto superficial dendrites of the cell in question were sufficient to maintain its visual responsivity. Unless there was some technical problem with the experiment, neurons giving this result would of necessity have dendrites that ascended into the superficial layers. 

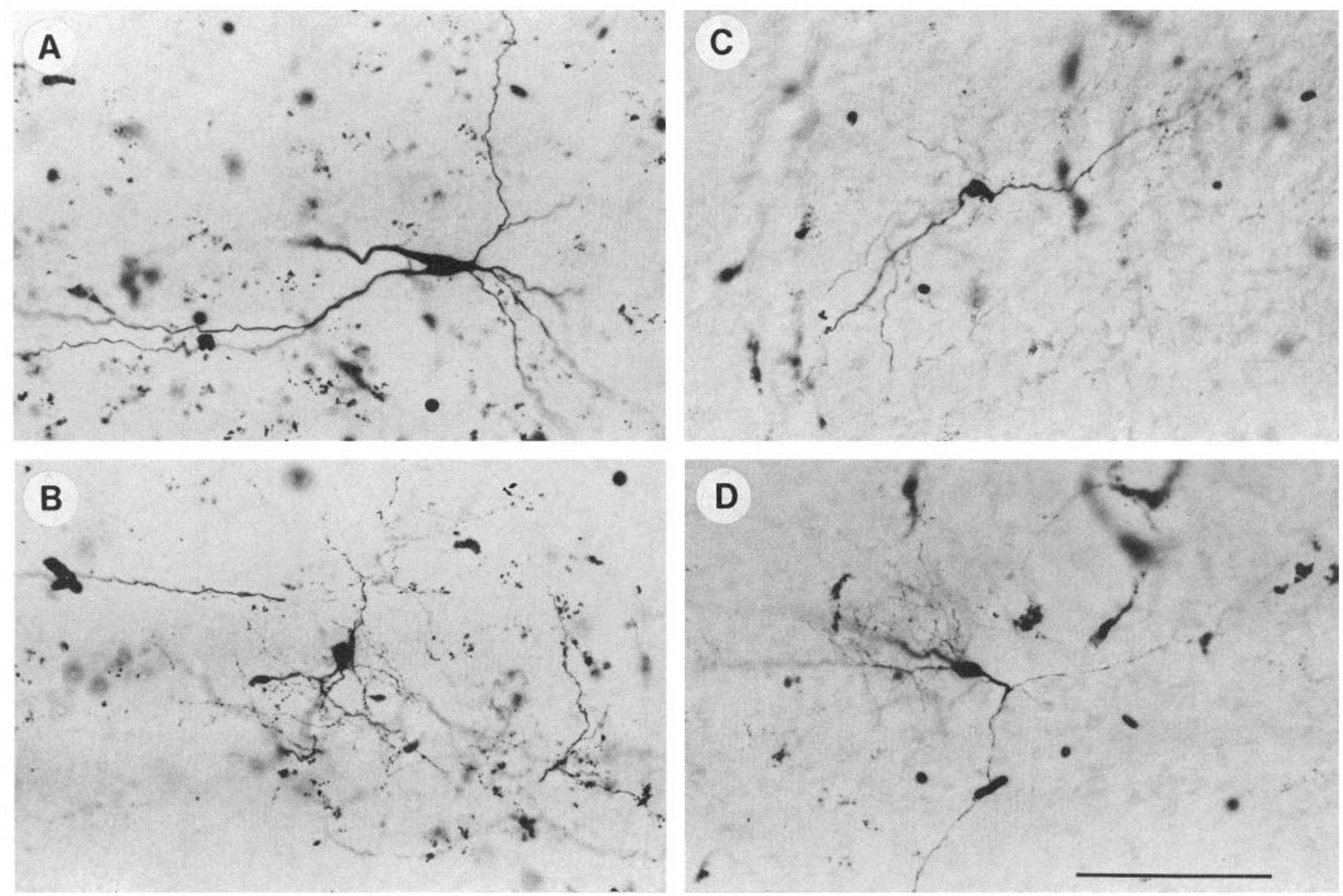

Figure 6. Photomicrographs of four deep layer cells that were tested with superficial layer injections of $\mathrm{CoCl}_{2}$. All of these neurons are reconstructed in Figure 7. Scale bar, $100 \mu \mathrm{m}$ (for $A-D$ ).

Thirty-seven deep layer neurons were tested during ejection of $\mathrm{CoCl}_{2}$ into the deep layers near the recorded cell. Of these cells, $59 \%(N=22)$ were significantly suppressed, and the remainder were unaffected, by injection of $\mathrm{CoCl}_{2}$ into the deep layers. The visual responses of $40 \%(N=15)$ of these cells were completely abolished by $\mathrm{CoCl}_{2}$ injection. The average percentage suppression was $58 \pm 42 \%$. Deep layer $\mathrm{CoCl}_{2}$ injections were significantly less effective than superficial layer injections, in terms of both the percentage of cells affected (Fisher's exact test, $p<0.0001)$ and the average percentage suppression $(t=$ $3.1 ; \mathrm{df}=127 ; p<0.01)$.

The responses of one deep layer neuron that was tested with deep $\mathrm{CoCl}_{2}$ injections are illustrated in Figure 8. This cell was recorded in the SGI and had a relatively small receptive field in the nasal visual field. It responded to OX stimulation with a latency of $4.0 \mathrm{msec}$ (Fig. $8 B$ ) and gave a vigorous response to moving spots of light (Fig. $8 D_{1}$ ). A small $\mathrm{CoCl}_{2}$ injection reduced both the visual response and spontaneous activity of the cell (Fig. $8 D_{2}$ ). A larger injection resulted in almost complete abolition of this cell's visual response (Fig. $8 D_{3}$ ). The $\mathrm{CoCl}_{2}$ injection also produced a very slight and insignificant decrement in the visual responses recorded from an electrode in the superficial layers (Fig. $8 C_{1}$ ). By $2 \mathrm{~min}$ after completion of the $\mathrm{CoCl}_{2}$ injections, the responses of the deep layer neuron had completely recovered.

The laminar distribution of the neurons tested with injections of $\mathrm{CoCl}_{2}$ into the deep layers is shown in Figure 9. As for the cells tested with superficial layer injections, there was no significant relationship between laminar location and the effect of $\mathrm{CoCl}_{2}$ injections upon visual responsivity $\left(\chi^{2}=1.1 ; \mathrm{df}=2 ; p\right.$ $=0.57$ ). There was also no significant relation between response latency to $\mathrm{OX}$ stimulation and whether or not a cell was affected by injection of $\mathrm{CoCl}_{2}$ (Fig. 10) $(t=0.4 ; \mathrm{df}=32 ; p=0.67)$. The average response latency for the cells whose visual responses were suppressed by $\mathrm{CoCl}_{2}$ injections was $8.9 \pm 3.6 \mathrm{msec}$, and that for cells that were not affected by such injections was 8.4 $\pm 2.8 \mathrm{msec}$.

Only eight cells that were tested with injection of $\mathrm{CoCl}_{2}$ into the deep layers were successfully impaled and filled with HRP. Four of these neurons had dendrites that ascended into the superficial layers, and only one had its visual responses suppressed by $\mathrm{CoCl}_{2}$ injection. Four cells had dendrites restricted to the deep layers, and the visual responses of three of these neurons were strongly suppressed by $\mathrm{CoCl}_{2}$ injections.

Data from two recovered cells are shown in Figure 11. These two neurons were recorded in two different electrode tracks made in the same hamster. The cell designated CO79A was located in the upper SGI and had dendrites that extended into the upper SGS, with some reaching as far as the pial surface (Fig. 11B). Its responses to OX (Fig. 11C) and visual (not illustrated) stimulation were not affected by $\mathrm{CoCl}_{2}$ injection into the deep layers. The neuron designated $\mathrm{CO} 79 \mathrm{~B}$ was iocated in the SAI and had dendrites that extended only as far as the middle of the SGI. Its responses to OX (Fig. 11C) and visual (not 

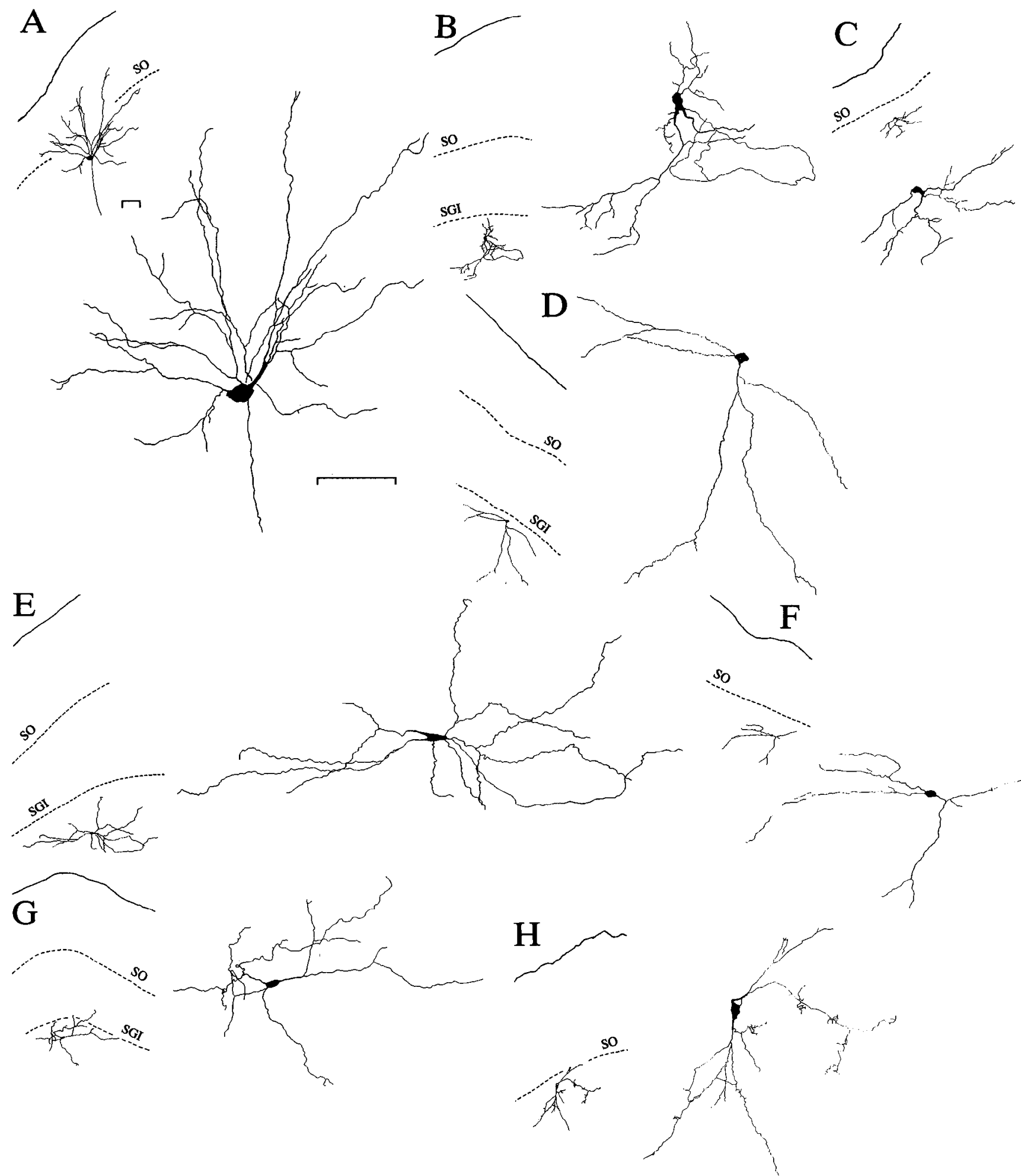

Figure 7. Low- and higher-power reconstructions of eight deep layer visual cells that were tested with superficial layer injections of CoCl ${ }_{2}$. Seven of these neurons had their visual responses significantly suppressed by these injections. The neuron in $B$ was not significantly affected by CoCl injection. The cells shown in $A$ and $H$ had dendrites that extended into the superficial layers. The remainder of the cells had dendrites restricted to the deep layers. The solid line in each of the low-power reconstructions indicates the SC surface, the upper broken line denotes the lower border of the SO, and the lower broken line indicates the lower border of the SGI. Scale bars, $100 \mu \mathrm{m}$ (for all panels).

illustrated) stimulation were nearly completely suppressed by $\mathrm{CoCl}_{2}$ injection.

Cells tested with both superficial and deep $\mathrm{CoCl}_{2}$ injections. We tested only two cells with both superficial and deep $\mathrm{CoCl}_{2}$ injections. Both of these neurons gave the same pattern of results; their visual and OX-evoked responses were abolished by $\mathrm{CoCl}_{2}$ injections into the superficial layers, but not by similar injections into the deep layers. The responses of these two neu- 
$\mathbf{A}$

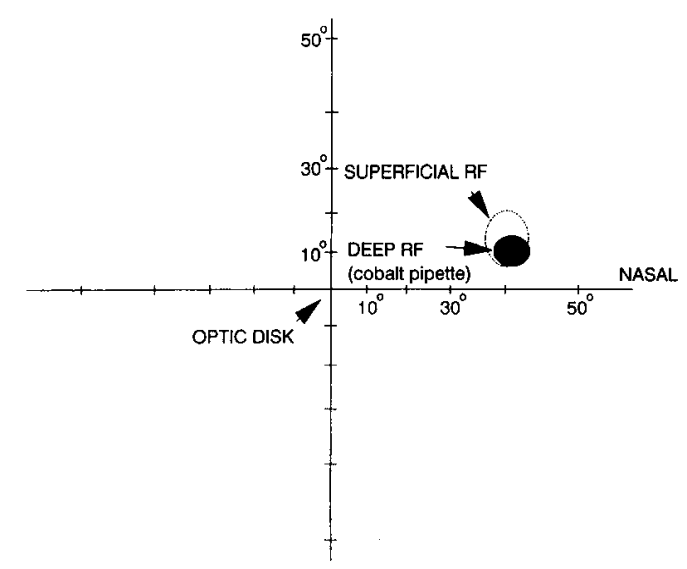

B

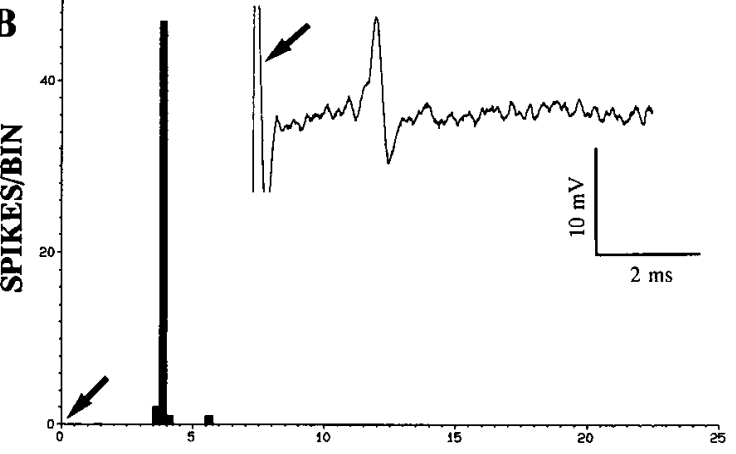

TIME (ms)
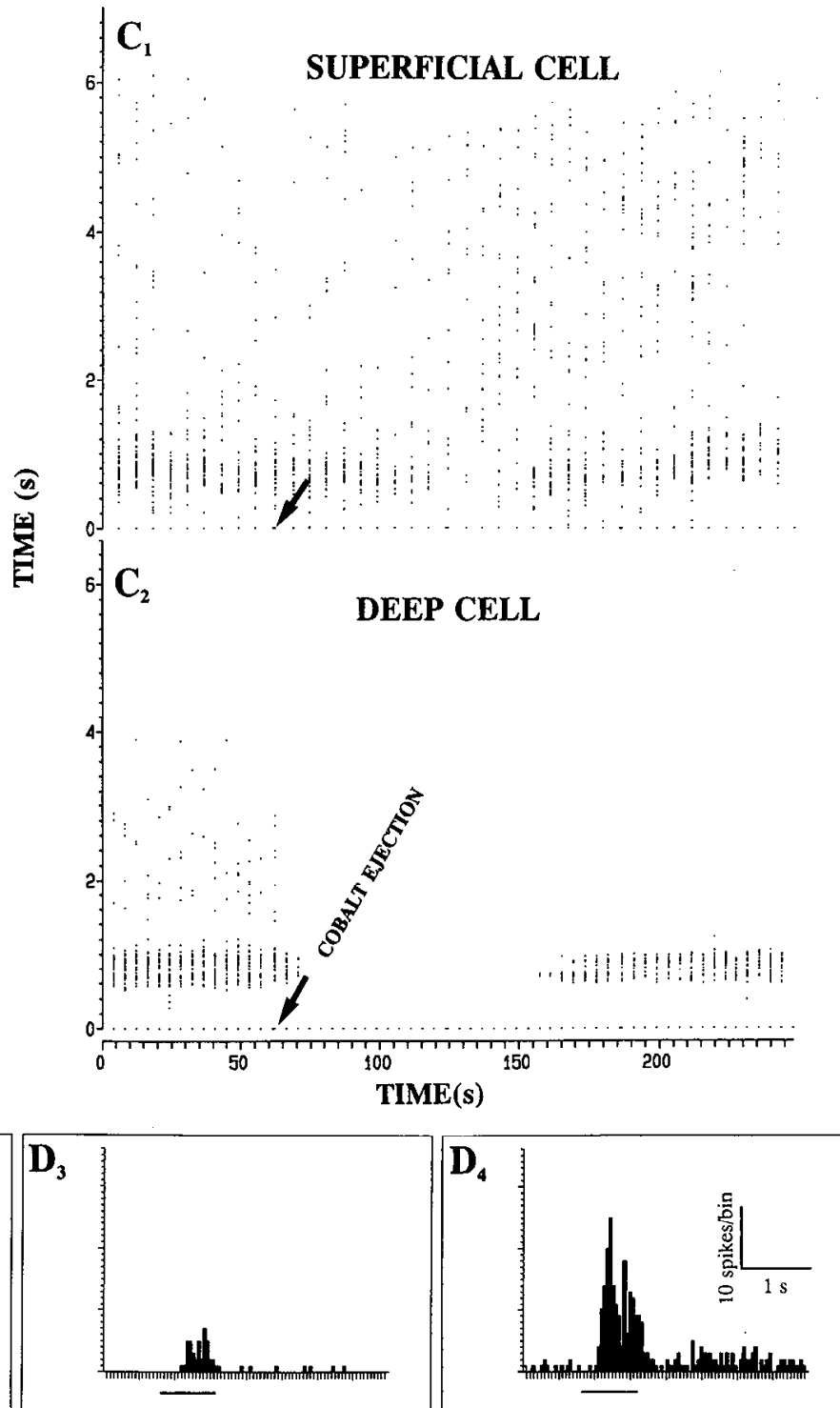

TIME (s)

Figure 8. Effects of deep $\mathrm{CoCl}_{2}$ injection upon the responses of one deep layer neuron. $A$ shows the location of the receptive field of the deep layer cell and of the receptive field of a unit recorded by an electrode in the overlying superficial layers. $B$ shows a PSTH (50 presentations) and an oscilloscope trace of the response of the deep layer cell to OX stimulation (the arrows denote the time of stimulation in the PSTH and shock artifact in the inset). $C_{1}$ and $C_{2}$ are raster displays that show the effect of the deep $\mathrm{CoCl}_{2}$ injection upon the visual responses evoked by a $6^{\circ}$ spot moving through the receptive field at $20 \% \mathrm{sec}$. The $\mathrm{CoCl}_{2}$ injection (arrows) resulted in a slight reduction of the responses of the superficial layer cell and a nearly complete loss of the responses of the deep layer neuron. $D_{1}-D_{4}$ are PSTHs of the responses of the decp laycr cell to the same stimulus made prior to $\mathrm{CoCl}_{2}$ injection $\left(D_{1}\right)$, after injection of $15 \mathrm{nl}\left(D_{2}\right)$, after injection of $25 \mathrm{nl}\left(D_{3}\right)$, and after recovery. The PSTHs were collected over 10 stimulus presentations. Lines below PSTHs show duration of the spot within the receptive field.

rons are of particular interest because they were bimodal (visualsomatosensory) neurons, and like the cell whose responses are shown in Figure 2, they provide information about the potential spread of our injections.

The cell whose responses are shown in Figure 12 was recorded in the SGI, $700 \mu \mathrm{m}$ below the SC surface. This cell had a visual field near the representation of the optic disk (Fig. 12A). Its somatosensory receptive field included most of the contralateral side of the hamster's face (Fig. $12 \mathrm{~B}$ ). Injection of $\mathrm{CoCl}_{2}$ into the superficial layers completely abolished the neuron's visual response (Fig. 12C), but not that elicited by an air puff delivered to the vibrissa pad (Fig. $12 \mathrm{D}$ ). Deep injection of $\mathrm{CoCl}_{2}$ abolished the somatosensory response and increased the visual response. These data show that the visual responses of this neuron depend upon synapses made in the superficial but not the deep SC layers and must therefore involve superficial dendrites of the neuron being recorded. The data from this cell are also of interest because they show that the superficial layer $\mathrm{CoCl}_{2}$ injection could not have spread into the deep layers, at least as far as the portion of the neuron that received its somatosensory input. They also show that an effective deep injection did not spread as far dorsally as the synapses that conferred visual responsivity upon this cell.

Control experiments. A pathway connecting the superficial with the deep SC layers via the ventral LGN (LGNv) was probably not involved in the effects described in the preceding paragraphs. We tested the visual- and OX-evoked responses of 16 cells during inactivation of the $\mathrm{LGNv}$ with $\mathrm{CoCl}_{2}$. None had 


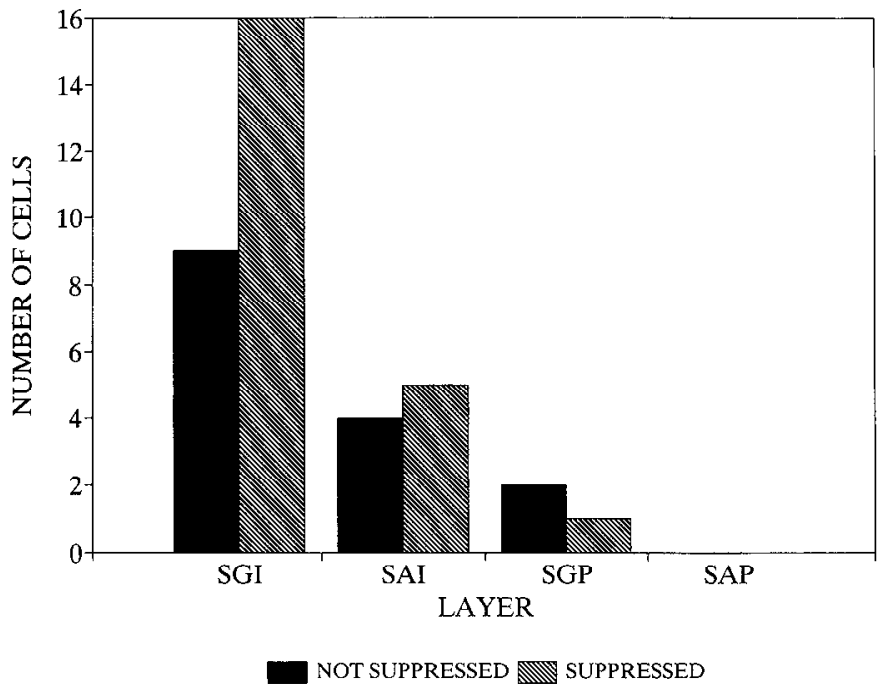

Figure 9. Laminar distributions of deep layer cells that were either significantly suppressed (hatched bars) or unaffected (solid bars) by injection of $\mathrm{CoCl}_{2}$ into the deep layers.

their responses significantly diminished by these injections. The responses of three $\mathrm{SC}$ cells tested with injection of $\mathrm{CoCl}_{2}$ into the LGNv are illustrated in Figure 13. None of these cells were affected by $\mathrm{CoCl}_{2}$ injections that completely abolished the responses of multiple-unit activity simultaneously recorded in the LGNv.

Superficial layer injections of $\mathrm{CoCl}_{2}$ sufficient to block the visual responses of deep layer visual neurons did not alter the somatosensory responses of either unimodal somatosensory or bimodal (visual-somatosensory) neurons. The assertion is supported by the data illustrated in Figures 2 and 12 and by recordings from four unimodal somatosensory cells whose responses were tested during injection of $\mathrm{CoCl}_{2}$ into the superficial layers and 15 bimodal neurons that had their visual, but not their somatosensory, responses suppressed by injection of $\mathrm{CoCl}_{2}$ into the superficial layers.

\section{Discussion}

The present results indicate that the visual responses of most deep layer neurons in the hamster's SC depend upon synapses made in the superficial layers and that these connections involve both superficial layer neurons that send axon collaterals into the deep layers and synapses onto dendrites of deep layer cells that extend into the superficial layers. The present results provide no support for the possibility that projections to the deep layers that do not either pass through or synapse in the superficial layers contribute substantially to the visual responses of deep layer neurons in the hamster's SC.

The conclusion that descending projections from the superficial to the deep SC layers in the hamster play an important role in organizing the visual responses of deep layer neurons is also supported by comparison of the representation of the visual field in the superficial and deep SC layers of this species. Both the trajectory of axons that descend from the superficial to the deep layers and the visual map in the deep layers in hamster are shifted laterally relative to projection lines orthogonal to the SC surface (Mooney et al., 1988; Rhoades et al., 1989). The combination of receptive field mapping and anterograde tracing with Phaseolus vulgaris leucoagglutinin showed further that dis-

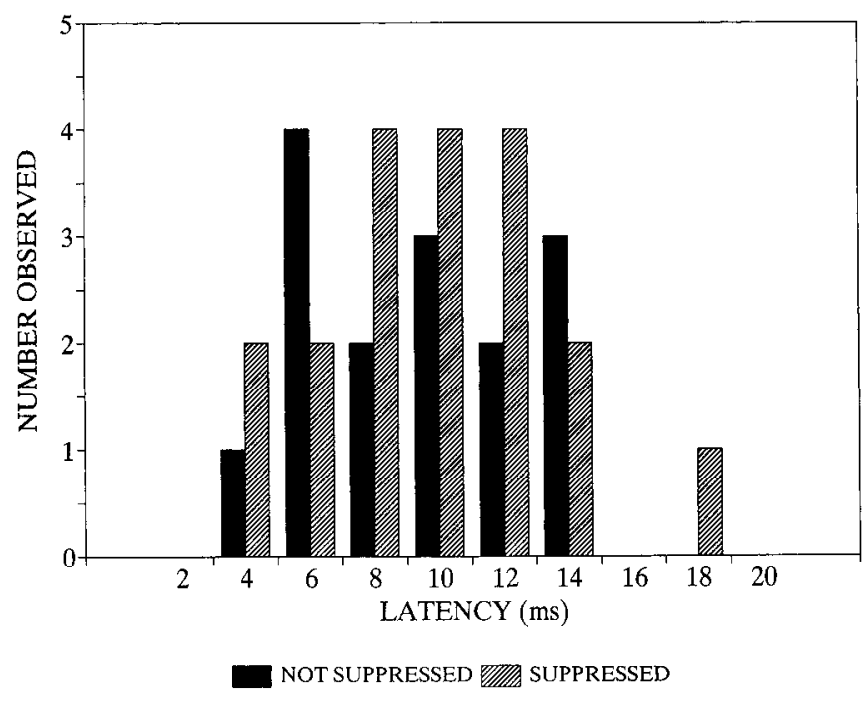

Figure 10. Histogram of response latencies to $\mathrm{OX}$ stimulation for deep layer cells either that were significantly suppressed by injection of $\mathrm{CoCl}_{2}$ into the superficial layers (hatched bars) or that were unaffected by such injections (solid bars). The mean ( \pm SD) latency for the formcr group was $8.9 \pm 3.6 \mathrm{msec}$, and that for the latter group was $8.4 \pm 2.8 \mathrm{msec}$ $(t=0.4 ; \mathrm{df}=32 ; p=0.67)$.

placement of the deep layer visual map closely matched the trajectory of the projection from the superficial layers to the deep layers (Rhoades et al., 1989). The conclusion drawn in that study, like that in the present report, was that the interlaminar projection in the hamster's SC was important for the development of the visual representation in the deep layers (Rhoades et al., 1989).

Technical limitations. Blockade of synaptic transmission in small volumes of neural tissue with $\mathrm{CoCl}_{2}$ has been used extensively by Malpeli and his colleagues (Malpeli, 1983; Malpeli et al., 1986; Schwark et al., 1986; Mignard and Malpeli, 1991), and they have provided extensive discussions of the limitations of this approach. $\Lambda \mathrm{n}$ additional problem in the present experiment was the very close proximity of the recording site to the location of the lidocaine and $\mathrm{CoCl}_{2}$ ejection electrodes. The combined depth of the SGS and SO in hamster is about 500 $\mu \mathrm{m}$, and this small distance created the possibility of spread of lidocaine or $\mathrm{CoCl}_{2}$ to the deep layers after superficial injections or of $\mathrm{CoCl}_{2}$ into the superficial layers after deep injections. Several observations indicated that such "leakage" was generally not a problem in the present experiments. The somatosensory responses of deep layer somatosensory and bimodal cells were generally not affected by lidocaine or $\mathrm{CoCl}_{2}$ injections into the superficial layers, and visual responses recorded in the superficial layers were usually not significantly reduced by deep layer $\mathrm{CoCl}_{2}$ injections. Furthermore, if leakage of $\mathrm{CoCl}_{2}$ into the deep layers occurred routinely, it might be expected that suppression of visual responses would be observed significantly more often in the SGI, the most dorsal of the deep layers, than in more ventral layers. This was not the case. We therefore believe it unlikely that our data were contaminated by false positive results arising from spread of either lidocaine or $\mathrm{CoCl}_{2}$.

It is more difficult to interpret the results of experiments in which $\mathrm{CoCl}_{2}$ injections into either the superficial or deep layers failed to reduce the visual responsivity of deep layer neurons. A negative result might reflect either an alternate pathway conveying visual information to the neuron being recorded or fail- 

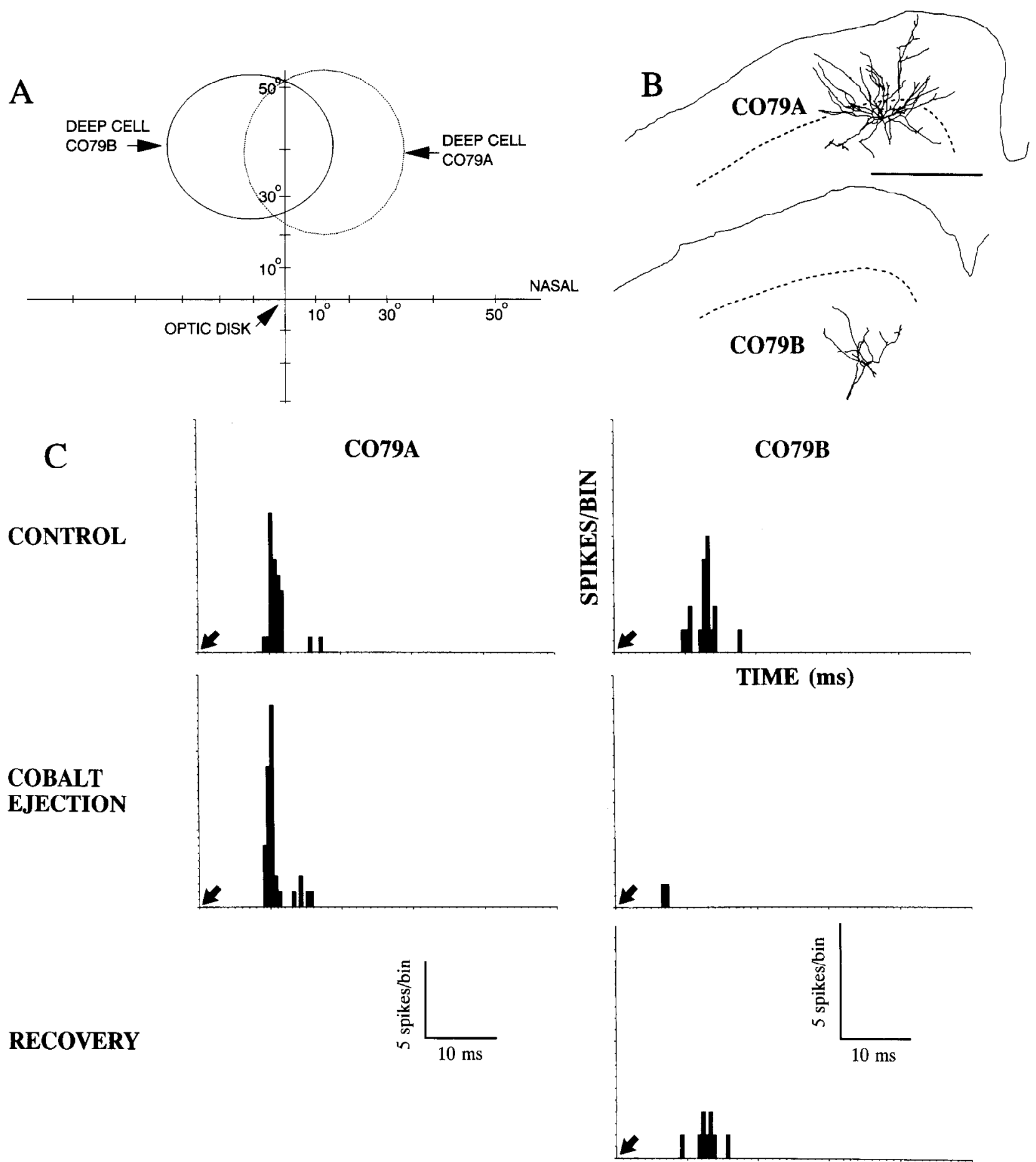

Figure 11. Effects of deep $\mathrm{CoCl}_{2}$ injections upon the $\mathrm{OX}$-evoked responses of two deep layer neurons that were injected with $\mathrm{HRP}$ and reconstructed. $A$ shows the receptive fields of the two cells, and $B$ provides reconstructions of the two neurons; cell $C O 79 A$ had dendrites that extended into the superficial layers, while the dendrites of cell $C O 79 B$ were restricted to the deep layers. The broken lines in the reconstructions denote the SO-SGI border, and the solid lines indicate the SC surface. Scale bar, $500 \mu \mathrm{m}$. C shows the responses of the cells to OX stimulation (arrows indicate times of occurrence) under control conditions and after injection of $\mathrm{CoCl}_{2}$ into the deep layers. The injection had no effect upon the responses of cell $C O 79 A$, but completely suppressed the responses of cell $C O 79 B$. The response of cell $C O 79 B$ was only partially recovered before it was impaled for HRP injection. Each PSTH was collected over 30 stimulus presentations.

ure of the injection to block synaptic transmission along the intended pathway. The addition of anatomical data from intracellular injection of HRP to the physiological results provided evidence that such false negative results did indeed occur. For example, in one instance, we recorded and recovered a cell with dendrites restricted to the deep layers and visual responses that were unaffected by deep $\mathrm{CoCl}_{2}$ injections. Such a result could have occurred only if our injections failed completely or did not encompass all of the dendritic arbor of the neuron being tested. We tested each $\mathrm{CoCl}_{2}$ electrode both before and after use and are confident that the former possibility did not occur in any of the experiments providing data for this article. However, our 

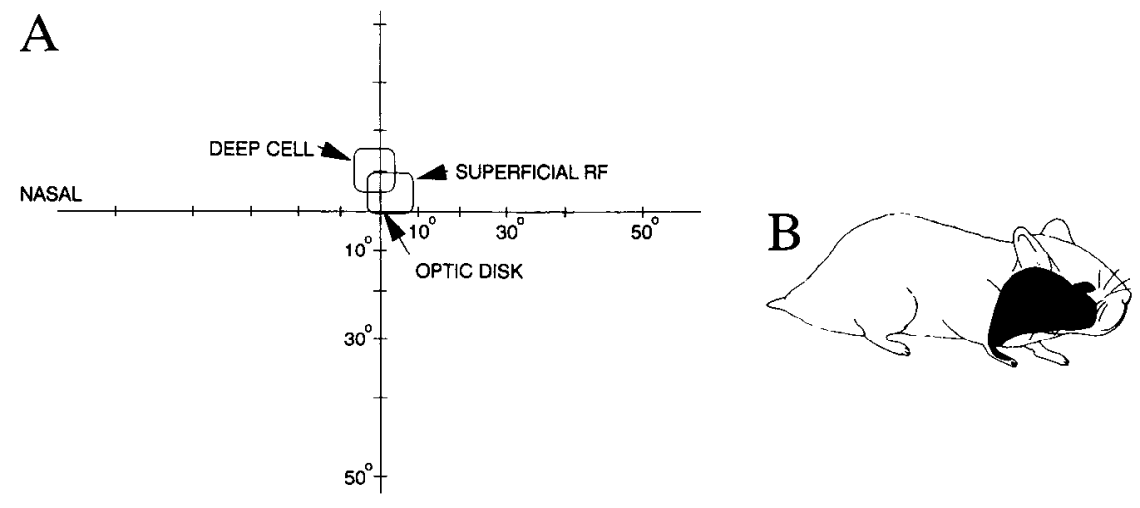

SUPERFICIAL COBALT EJECTION

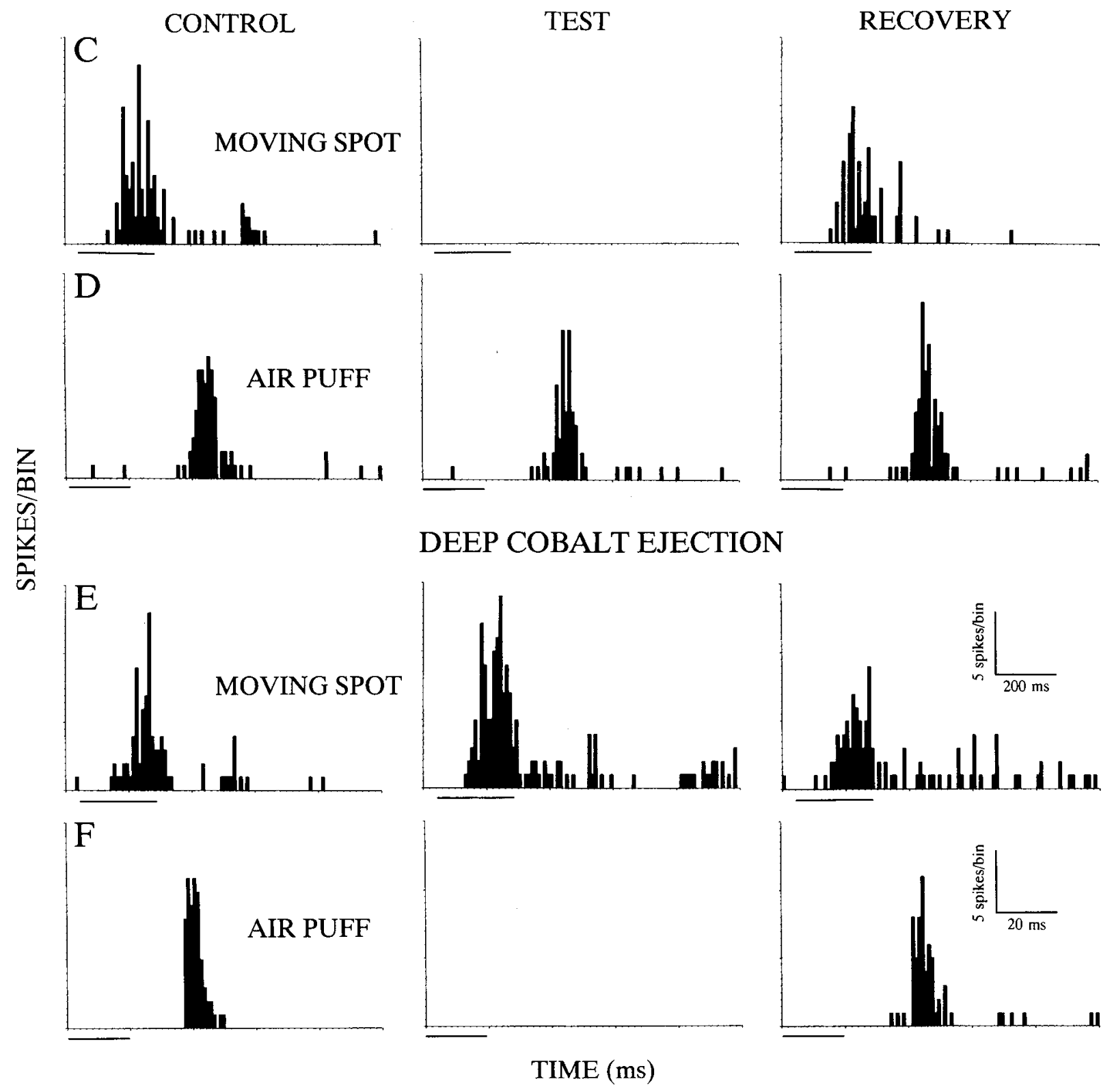

Figure 12. Effects of superficial and deep $\mathrm{CoCl}_{2}$ injections upon the responses of a bimodal cell recorded within the SGI. $A$ shows the location of the cell's visual receptive field and that of the activity recorded by the $\mathrm{CoCl}_{2}$ injection electrode in the superficial layers. $B$ shows the cell's somatosensory receptive field (solid section). $C$ and $D$ show the effect of a superficial $\mathrm{CoCl}_{2}$ injection ( $25 \mathrm{nl}$ ) upon the responses of the cell to a spot moved across the receptive field ( $3^{\circ}$ diameter, $40^{\circ} / \mathrm{sec}$ ) or an air puff (all PSTHs are from 25 presentations; lines below PSTHs indicate stimulus occurrences). $E$ and $F$ show the effects of a deep $\mathrm{CoCl}_{2}$ injection $(25 \mathrm{nl})$ upon the responses elicited by the same stimuli. The calibrations in $E$ and $F$ also apply, respectively, to $C$ and $D$. 
assessment of the spread of $\mathrm{CoCl}_{2}$ injections and what is known about the dendritic arbors of deep layer SC cells in hamster (Mooney et al., 1984; Rhoades et al., 1986, 1987) suggest strongly that our deep $\mathrm{CoCl}_{2}$ injections may not have included all of the deep dendritic arbors of some of the cells we recorded. Measurements in the superficial SC layers during $\mathrm{CoCl}_{2}$ injections indicated that synaptic transmission was suppressed in a volume of tissue with a radius of about $125 \mu \mathrm{m}$. Thus, a $\mathrm{CoCl}_{2}$ site can be no more than $125 \mu \mathrm{m}$ away from a site of synaptic contact to block transmission effectively. Some deep layer cells, especially those sending axons to the spinal cord, have dendritic arbors that exceed $500 \mu \mathrm{m}$ in diameter.

Caution is also warranted in interpreting the results of experiments in which superficial layer $\mathrm{CoCl}_{2}$ injections failed to reduce the visual responses of deep layer neurons. The projection from the superficial to the deep layers of the hamster's SC is topographically organized (Rhoades et al., 1989), but the interlaminar axons arising from a given location in the superficial layers have a relatively widespread termination in the deep layers. Thus, a portion of the superficial layers not silenced by our $\mathrm{CoCl}_{2}$ electrodes may have provided input to a given deep layer neuron.

In summary, the controls carried out provide support for the conclusion that the present data were not contaminated by false positive results associated with excessive spread of lidocaine or $\mathrm{CoCl}_{2}$ injections, but previous anatomical findings and some of the data from the present study indicate that negative findings must be interpreted with caution and that our results may underestimate the percentage of deep layer neurons whose visual responses are reduced or abolished by interference with interlaminar connections.

Anatomical substrates for the visual responses of deep layer cells and their importance in different species. There are two distinct classes of pathways by which visual information might reach deep layer $\mathrm{SC}$ neurons. The first have their origins outside the $\mathrm{SC}$ and include direct retinal projections to the deep layers (Berson and McIlwain, 1982; Beckstead and Frankfurter, 1983; Mooney and Rhoades, 1990), the $\mathrm{LGNv} \rightarrow \mathrm{SC}$, projection (Edwards et al,, 1974; Graybiel, 1974; Ribak and Peters, 1975; Hayashi and Nagata, 1981), visual cortical projections to the deep layers (Garey et al., 1968; Kawamura et al., 1974; Updyke, 1977; Baleydier et al., 1983; Segal and Beckstead, 1984; Harvey and Worthington, 1990), and the visual cortex $\rightarrow$ caudate nucleus $\rightarrow$ substantia nigra pars reticulata $\rightarrow$ deep SC layers pathway (e.g., Graybiel, 1978; Rhoades et al., 1982).

Intrinsic SC projections are a second type of pathway that might provide visual input to deep layer neurons and include the extension of the dendrites of deep layer cells into the superficial layers (Viktorov, 1968; Tokunaga and Otani, 1976; Norita, 1980; Mooney et al., 1984; Grantyn et al., 1984; Moschovakis and Karabelas, 1985), where they might receive input from retina, visual cortex, and/or local axon collaterals of SC cells. Axonal projections from the superficial layers to the deep layers (Sprague, 1975; Grantyn et al., 1984; Mooney et al., 1985, 1988; Moschovakis et al., 1988; Rhoades et al., 1989) might also support the responses of deep layer visual cells. Review of the literature suggests that different pathways to the deep layers have differing functional importance in different species. The following sections address this issue.

Functional influences of extrinsic visual projections to deep layer neurons. The influence of visual cortical projections upon the responses of neurons in the deep layers of the SC has been

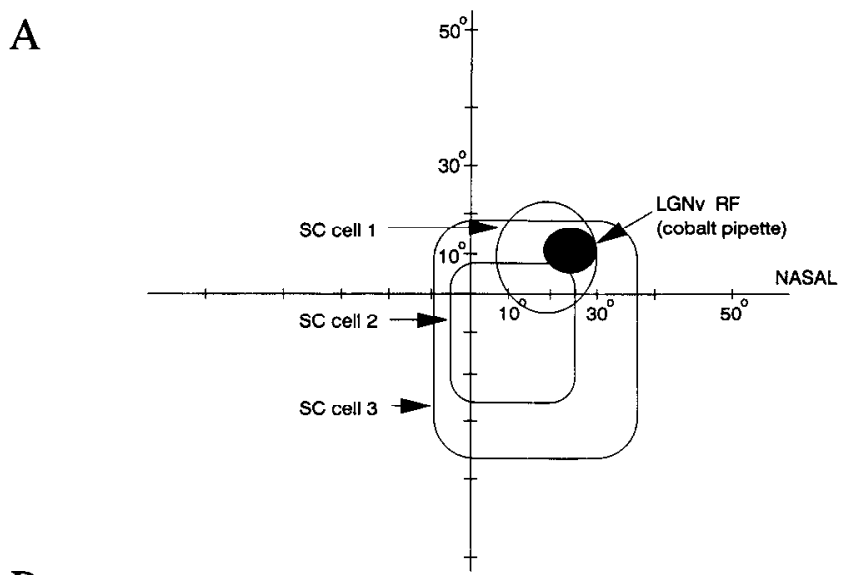

B
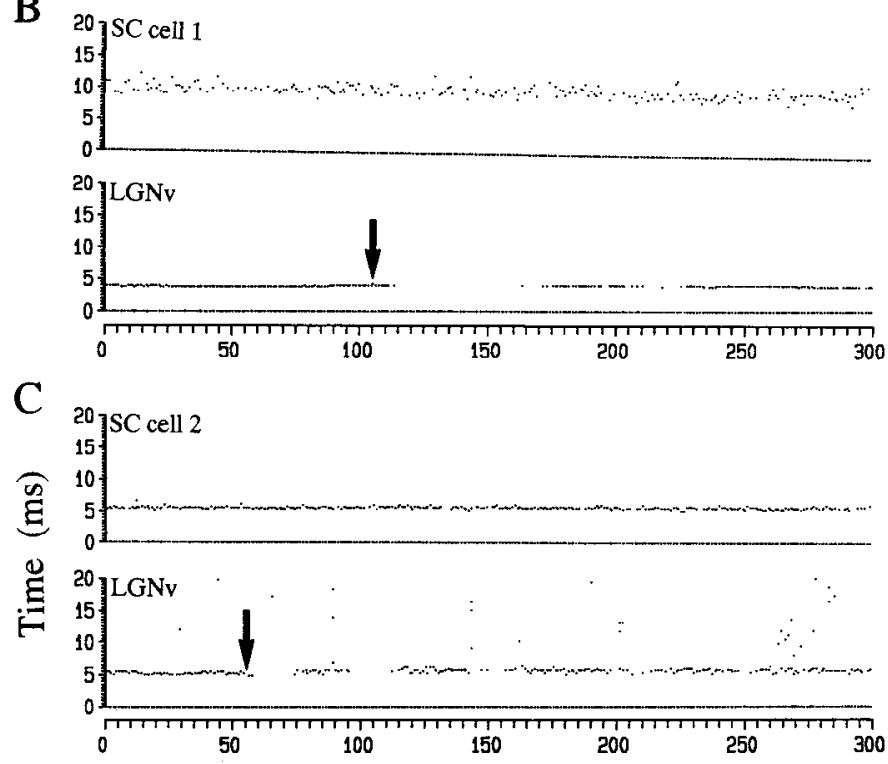

D
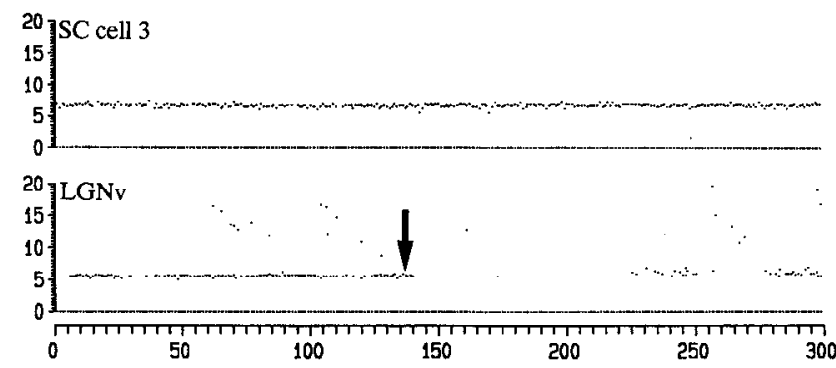

Time (s)

Figure 13. Results from an experiment in which $\mathrm{CoCl}_{2}$ was injected into LGNv while multiple-unit activity in this nucleus and neurons in the ceep SC layers were simultaneously recorded. $A$ shows the location of the receptive field for the multiple-unit activity recorded by the LGNv electrode and for three deep layer SC cells recorded in this experiment. $B-D$ are raster displays that show the responses of the $L G N v$ activity (the lower member of each pair) and each SC cell to OX stimulation. The times when $\mathrm{CoCl}_{2}$ was injected are denoted by the arrows. Note the total loss of LGNv activity shortly after the $\mathrm{CoCl}_{2}$ injection and the lack of effect upon the responses of any of the SC cells.

studied extensively. Visual cortical input is required for the visual responsivity of all deep layer $\mathrm{SC}$ neurons in the macaque. Cooling or ablation of area 17 in this species completely abolished the visual responses of deep layer cells, but had little effect upon superficial layer neurons (Schiller et al., 1974). Since area 
17 does not project to the deep SC layers in macaque (Ogren and Hendrickson, 1976; Ungerleider et al., 1984), it seems likely that this effect must have been mediated via an indirect link interconnecting the striate cortex with the deep layers or via connections between cortical axons and superficial dendrites of deep layer neurons (Moschovakis et al., 1988).

Large lesions that include areas 17,18 , and 19 have little influence upon the visual responses of deep layer neurons in the cat's SC (Rizzolatti et al., 1970; Mize and Murphy, 1976). However, both Stein and Arigbede (1972) and Stein (1978) demonstrated that cooling large regions of the posterior neocortex in cat reduced the responses of many unimodal visual cells in the deep layers and completely abolished the visual responses of multimodal neurons in these layers. Ogasawara et al. (1984) and IIardy and Stein (1988) showed further that these same effects could be obtained by either cooling or ablation of the posterior suprasylvian cortex.

In the ground squirrel (Michael, 1971, 1972), many deep layer visual cells have hypercomplex receptive fields, and no such neurons can be recorded after visual cortical lesions of unspecified sizes. However, directionally selective visual neurons with properties nearly identical to one class of retinotectal axon (Michael, 1972) still remain in the deep SC layers of such animals. It may be that the responsivity of these neurons was dependent upon contacts from that class of retinal axon.

Large lesions of the posterior neocortex in hamster and rabbit do not appreciably alter the visual responses of deep layer SC cells (Stewart et al., 1973; Chalupa and Rhoades, 1977; Finlay et al., 1978; Graham et al., 1982). In considering these results, it is important to note that neither these experiments nor the present study determined whether corticotectal projections could sustain the visual responsivity of deep layer neurons in the absence of other visual inputs to these layers.

The present results suggest that direct retinal projections to the deep layers may contribute significantly to the visual responses of a number of deep layer neurons in the hamster's SC. The conclusion is supported by the observation that injection of lidocaine into the superficial layers abolished the visual responses of all deep layer cells tested while similar injections of $\mathrm{CoCl}_{2}$ had little effect upon the responses of about $14 \%$ of the neurons tested. This result means that some deep layer neurons had visual responses dependent upon fibers that passed through, but probably did not synapse in, the superficial layers. Given the previous result that ablation of the posterior neocortex does not reduce the visual responsivity of deep layer neurons in hamster (Chalupa and Rhoades, 1977; but see below for an important limitation of these results), retinal axons that travel in the SO before giving off deep layer collaterals (Mooney and Rhoades, 1990) seem the most likely candidate for the mediation of these responses. Berson and Mcllwain (1982) showed that $34 \%$ of the neurons in the deep layers of the cat's SC received direct input from retinal $Y$-cells, but they did not determine whether these neurons were visually responsive. Given the fact that the dendrites of at least some deep layer neurons in the cat's SC extend into the superficial layers (Moschovakis and Karabelas, 1985), it is also not clear whether the retinal synapses onto these neurons were made in the superficial layers, the deep layers, or both.

The role that the $\mathrm{LGNv} \rightarrow \mathrm{SC}$ pathway may play in the visual responses of deep layer neurons is not clear. Our $\mathrm{CoCl}_{2}$ injections into the LGNv did not alter the visual responsivity of any of the small sample of SC cells that we tested.

It seems unlikely that indirect inputs via the basal ganglia play a substantial role in the visual responsivity of SC cells. Experiments in both rat (Deniau et al., 1978) and monkey (Hikosaka and Wurtz, 1983b, 1985a,b) have demonstrated that the substantia nigra pars reticulata sends a powerful inhibitory input to the deep SC layers. Several studies, particularly that of $\mathrm{Hi}$ kosaka and Wurtz (1983a), have shown further that some nigral neurons have visual receptive fields and that their firing rates are reduced by visual stimulation. However, comparison of the visual responses of deep layer SC cells and nigrotectal neurons indicates that it is unlikely that the latter cells provide the essential visual input to the deep layers. Most importantly, Hikosaka and Wurtz (1983b) have shown that visual response latencies of substantia nigra cells in macaque are longer than those of deep layer SC neurons. Thus, the nigrotectal input could only contribute to the later components of the visual response of deep layer SC cells. The observations that no deep layer visual responses survived injection of lidocaine into the superficial layers and that visual cortical ablations did not reduce deep layer visual responses (Chalupa and Rhoades, 1977) provide further evidence that a visual cortex $\rightarrow$ striatum $\rightarrow$ substantia nigra pars reticulata $\rightarrow$ deep SC layers pathway is insufficient to confer visual responsivity upon deep layer neurons in this species.

Functional influences of intrinsic SC projections to deep layer neurons. The present results support the possibility that both the extension of dendrites into the superficial layers by deep layer neurons and descending axonal projections of superficial layer cells may provide visual input necessary for the responses of many deep layer neurons. The best evidence that extension of dendrites into the superficial layers and the contacts they receive may support the visual responsivity of deep layer cells comes from the small number of HRP-filled cells that were tested with deep layer $\mathrm{CoCl}_{2}$ injections. Three of the four cells with superficial dendrites had visual responses that were not significantly affected by $\mathrm{CoCl}_{2}$ injections into the deep layers, while three of the four neurons with dendrites restricted to the deep layers had their visual responses abolished by $\mathrm{CoCl}_{2}$ injections into the deep layers. Analysis of HRP-filled deep layer $\mathrm{SC}$ cells in hamster has indicated that about one-third of these neurons have dendrites that extend into the superficial layers (Mooney et al., 1984). These findings and the results of the present study suggest that these translaminar dendrites may contribute to the visual responses of a substantial portion of deep layer neurons.

In the present study, the most consistent effect of $\mathrm{CoCl}_{2}$, when injected into the superficial layers, was reduction or abolition of the visual responses of deep layer cells. This effect occurred in $86 \%$ of the cells tested, and it provides further support for the conclusion that intrinsic SC projections are essential for the visual responses of most deep layer neurons in the hamster's $\mathrm{SC}$. Given the fact that superficial $\mathrm{CoCl}_{2}$ injections suppressed the responses of many deep layer cells with dendrites that did not extend into the superficial layers, these results support the conclusion that superficial layer cells with axonal projections to the deep layers (about $40 \%$ of the neurons in the superficial layers have such axons; Mooney et al., 1988) contribute substantially to the responses of deep layer cells in the hamster SC.

\section{References}

Adams JC (1981) Heavy metal intensification of DAB-based HRP reaction product. J Histochem Cytochem 29:775.

Baleydier C, Kahungu M, Mauguiere F (1983) A crossed corticotectal projection from the lateral suprasylvian area in the cat. J Comp Neurol 214:344-351. 
Beckstead RM, Frankfurter A (1983) A direct projection from the retina to the intermediate gray layer of the superior colliculus demonstrated by anterograde transport of horseradish peroxidase in monkey, cat and rat. Exp Brain Res 52:261-268.

Berson DM, McIlwain JT (1982) Retinal Y-cell activation of deeplayer cells in superior colliculus of the cat. J Neurophysiol 47:700714.

Chalupa LM, Rhoades RW (1977) Responses of visual, somatosensory and auditory neurons in the golden hamster's superior colliculus. J Physiol (I ond) 270:595-626.

Chalupa LM, Rhoades RW (1978) Modification of visual response properties in the superior colliculus of the golden hamster following stroboscopic rearing. J Physiol (Lond) 274:571-592.

Deniau JM, Chevalier G, Feger J (1978) Electrophysiological study of the nigro-tectal pathway in the rat. Neurosci Lett 10:215-220.

Drager UC, Hubel DH (1975) Responses to visual stimulation and relationship between visual, auditory and somatosensory inputs in mouse superior colliculus. J Neurophysiol 38:690-713.

Edwards SB, Kosenquist AC, Palmer LS (1974) An autoradiographic study of ventral lateral geniculate projections in the cat. Brain Res 92:341-368.

Fernald R, Chase R (1971) An improved method for plotting retinal landmarks and focusing the eyes. Vision Res 11:95-96.

Finlay BI, Schneps SF, Wilson KG, Schneider GE (1978) Topography of visual and somatosensory projections to the superior colliculus of the golden hamster. Brain Res 142:223-235.

Garey JL, Jones EG, Powell TPS (1968) Interrelationships of striatc and extrastriate cortex with primary relay sites of the visual pathway. J Neurol Neurosurg Psychiatr 31:135-157.

Gordon B (1973) Receptive fields in deep layers of cat superior colliculus. J Neurophysiol 36:157-178.

Graham J, Berman N, Murphy EH (1982) Effects of visual cortical lesions on receptive-field properties of single units in superior colliculus of the rabbit. J Neurophysiol 47:272-286.

Grantyn R, Ludwig R, Eberhardt W (1984) Neurons of the superficial tectal gray. An intracellular HRP-study on the kitten superior colliculus in vitro. Exp Brain Res 55:172-176.

Graybiel AM (1974) Visuo-cerebellar and cerebello-visual connections involving the ventral lateral geniculate nucleus. Exp Brain Res 20:303-306.

Graybiel AM (1978) Organization of the nigrotectal connection: an experimental tracer study in the cat. Brain Res 143:339-348.

Hardy SC, Stein BG (1988) Small lateral suprasylvian cortex lesions produce visual neglect and decreased visual activity in the superior colliculus. J Comp Neurol 273:527-542.

Harvey AR, Worthington DR (1990) The projection from different visual cortical areas to the rat superior colliculus. J Comp Neurol 298:281-292.

Hayashi Y, Nagata T (1981) Receptive field properties of rat ventral lateral geniculate cells projecting to the superior colliculus. Brain Res 226:298-303.

Hikosaka O, Wurtz RH (1983a) Visual and oculomotor functions of monkey substantia nigra pars reticulata. I. Relation of visual and auditory responses to saccades. J Neurophysiol 49:1230-1253.

Hikosaka O, Wurtz RH (1983b) VIsual and oculomotor functions of monkey substantia nigra pars reticulata. IV. Relation of substantia nigra to superior colliculus. J Neurophysiol 49:1285-1301.

Hikosaka O, Wurtz RH (1985a) Modification of saccadic eye movements by GABA-related substances. I. Effects of muscimol and bicuculline in monkey superior colliculus. J Neurophysiol 53:266-291.

Hikosaka O, Wurtz RH (1985b) Modification of saccadic eye move. ments by GABA-related substances. II. Effects of muscimol in monkey substantia nigra pars reticulata. J Neurophysiol 53:292-308.

Janig W, Schoultz T, Spencer WA (1977) Temporal and spatial parameters of excitation and afferent inhibition in cuneothalamic relay neurons. J Neurophysiol 40:822-835.

Kawamura S, Sprague JM, Niimi K (1974) Corticofugal projections from the visual cortices to the thalamus, pretectum and superior colliculus in the cat. J Comp Neurol 158:339-362.

Larson MA, McHaffie JG, Stein BE (1987) Response properties of nociceptive and low-threshold mechanoreceptive neurons in the hamster superior colliculus. J Neurosci 7:547-564.

Malpeli JG (1983) Activity of cells in area 17 of the cat in absence of input from layer $A$ of lateral geniculate nucleus. J Neurophysiol 49: $595-610$
Malpeli JG, Lee C, Schwark HD, Weyand TG (1986) Cat area 17. I. Pattern of thalamic control of cortical layers. J Neurophysiol 56:10621073.

Meredith MA, Stein BE (1986) Spatial factors determine the activity of multisensory neurons in cat superior colliculus. Brain Res 365: 350-354.

Michael CR (1971) Visual response properties and functional organization of cells in the superior colliculus of the ground squirrel. Vision Res 3:299-308.

Michael CR (1972) Functional organization of cells in superior colliculus of the ground squirrel. J Neurophysiosl 6:833-846.

Mignard M, Malpeli JG (1991) Paths of information flow through visual cortex. Science 251:1249-1251.

Mize RR, Murphy EH (1976) Alteration in receptive field properties of superior colliculus cells produced by visual cortex ablation in infant and adult cats. J Comp Neurol 168:393-424.

Mooney RD, Rhoades RW (1990) Relationships between physiological and morphological properties of retinocollicular axons in the hamster. J Neurosci 10:3164-3177.

Mooney RD, Klein BG, Jacquin MF, Rhoades RW (1984) Dendrites of deep layer, somatosensory superior collicular neurons extend into the superficial laminae. Brain Res 324:361-365.

Mooney RD, Klein BG, Rhoades RW (1985) Correlations between the structural and functional characteristics of neurons in the superficial laminae of the hamster's superior colliculus. J Neurosci 5:2989_ 3009.

Mooney RD, Nikoletscas MM, Ruiz SA, Rhoades RW (1988) Thc projection from the superficial to the deep layers of the superior colliculus: an intracellular horseradish peroxidase injection study in the hamster. J Neurosci 8:1384-1399.

Mooney RD, Bennett-Clarke C, Chiaia NL, Sahibzada N, Rhoades RW (1990) Organization and actions of the noradrenergic input to the hamster's superior colliculus. J Comp Neurol 292:214-230.

Moschovakis AK, Karabelas AB (1985) Observations on the somatodendritic morphology and axonal trajectory of intracellularly HRP. labeled efferent neurons located in the deeper layers of the superior colliculus of the cat. J Comp Neurol 239:276-308.

Moschovakis AK, Karabelas AB, Highstein SM (1988) Structurefunction relationships in the primate superior colliculus. I. Morphological classification of efferent neurons. J Neurophysiol 60:232-262.

Norita M (1980) Neurons and synaptic patterns in the deep layers of the superior colliculus of the cat. A Golgi and electron microscopic study. J Comp Neurol 190:29-48.

Ogasawara K, McHaffie JG, Stein BG (1984) Two visual corticotectal systems in cat. J Neurophysiol 52:1226-1245.

Ogren M, Hendrickson A (1976) Pathways between striate cortex and subcortical regions in Macaca mulatta and Saimiri sciureus: evidence for a reciprocal pulvinar connection. Exp Neurol 53:780-800.

Powers MK, Green DG (1978) Single retinal ganglion cell responses in the dark-reared rat: grating acuity, contrast sensitivity, and defocusing. Vision Res 18:1533-1539.

Rhoades RW, Kuo DC, Polcer JD, Fish SE, Voneida TJ (1982) Indirect visual cortical input to the deep layers of the hamster's superior colliculus via the basal ganglia. J Comp Neurol 208:239-254.

Rhoades RW, Mooney RD, Jacquin MF (1983) Complex somatosensory receptive fields of cells in the deep laminae of the hamster's superior colliculus. J Neurosci 3:1342-1354.

Khoades RW, Mooney RD, Szczepanik AM, Klein BG (1986) Structural and functional characteristics of commissural neurons in the superior colliculus of the hamster. J Comp Neurol 253:197-215.

Rhoades RW, Mooney RD, Klein BG, Jacquin MF, Szczepanik AM Chiaia NL (1987) The structural and functional characteristics of tectospinal neurons in the golden hamster. J Comp Neurol 255:451465.

Rhoades RW, Mooney RD, Rohrer WH, Nikoletseas MM, Fish SE (1989) Organization of the projection from the superficial to the deep layers of the hamster's superior colliculus as demonstrated by the anterograde transport of Phaseolus vulgaris leucoagglutinin. J Comp Neurol 283:54-70.

Ribak CE, Peters A (1975) An autoradiographic study of the projections from the lateral geniculate body of the rat. Brain Res 92:341368.

Rizzolatti G, Tradardi V, Camarda R (1970) Unit responses to visual stimuli in the cat's superior colliculus after removal of the visual cortex. Brain Res 24:336-339. 
Schiller PH, Stryker M, Cynader M, Berman N (1974) Response characteristics of single cells in the monkey superior colliculus following ablation or cooling of visual cortex. J Neurophysiol 37:181-194.

Schwark HD, Malpeli JG, Weyand TG, Lee C (1986) Cat area 17. II Response properties of infragranular layer neurons in the absence of supragranular layer activity. J Neurophysiol 56:1074-1087.

Segal RL, Beckstead RM (1984) The lateral suprasylvian corticotectal projection in cats. J Comp Neurol 225:259-275.

Sprague JM (1975) Mammalian tectum: intrinsic organization, afferent inputs, and integrative mechanisms. Neurosci Res Program Bull $13: 204-214$

Stein BE (1978) Nonequivalent visual, auditory, and somatic corticotectal influences in cat. J Neurophysiol 41:55-64.

Stein BE, Arigbede MO (1972) Unimodal and multimodal response properties of neurons in the cat's superior colliculus. Exp Neurol 36: 179-196.
Stewart DL, Birt D, Towns LC (1973) Visual receptive-field characteristics of superior colliculus neurons after cortical lesions in the rabbit. Vision Res 13:1965-1977.

Tiao YC, Blakemore C. (1976) Functional organization in the superior colliculus of the golden hamster. J Comp Neurol 168:483-504.

Tokunaga A, Otani K (1976) Dendritic patterns of neurons in the rat superior colliculus. Exp Neurol 52:189-205.

Ungerleider LG, Desimone R, Galkin TW, Mishkin M (1984) Subcortical projections of area MT in the macaque. J Comp Neurol 223 : 368-386.

Updyke BV (1977) Topographic organization of the projections from cortical areas 17,18 , and 19 onto the thalamus, pretectum and superior colliculus in the cat. J Comp Neurol 173:81-122.

Viktorov IV (1968) Neuronal structure of superior colliculi of corpora quadrigemina. Arkh Anat Gistol Embriol 54:45-55. 